\title{
Recent Advances in Matrix Metalloproteinase Research
}

\author{
マトリックスメタロプロテアーゼ研究の最近の進歩
}

Christopher Mark OVERALL

Faculty of Dentistry, University of British Columbia, Vancouver, British Columbia V6T 1Z3, Canada, FAX: 1-604-822-3562

\begin{abstract}
Several homologous connective tissue matrix degrading metalloproteinases, termed matrix metalloproteinase(MMPs), are secreted by resident tissue cells, infiltrating inflammatory cells, and tumor cells as inactive proenzymes that, upon activation, can degrade many of the connective tissue components. cDNA sequence analysis has revealed that these proteinases are composed of several modules, some of which appear to have been derived from matrix proteins. A family of specific tissue inhibitors of MMP(TIMPs) regulates the extracellular activity of MMPs. MMPs and TIMPs are differentially regulated in cells by growth factors, hormones and cell shape changes. Recent work has shown that lectins also stimulate MMP expression and suppresses TIMP levels in human fibroblasts indicating that naturally present lectins may also participate in regulating MMP and TIMP gene expression in vivo.
\end{abstract}

要 旨 マトリックスメタロプロテアーゼ(MMPs)と名付けられ た、互いに性質のよく似た幾つかの䊅合組織分解金属プロテア 一ゼは、組織に存在する細胞や、炎症時の炎症細胞や腫瘍細胞 から、活性のないブロ䣼として分泌され、活性化を受けてか ら多くの結合組織成分を分解出来るようになる。cDNA配列の 分析から、これらのプロテアーゼが数個のモジュールからな ク、その中の幾つかはマトリックスタンパクから由来している ことが明らかとなった。MMPsに対して特異的な一群の組織性 阻害物質(TIMPs)がMMPsの細胞外での活性を調節している。細 胞に於けるMMPs とTIMPsは成長因子類、ホルモン、細胞の形 態変化などによって別々に調節されている。最近、レクチンも またヒト線維芽細胞の系で、MMP発現を励起し、TIMP量を抑 制することが示された。この䊅果は、天然に存在するレクチン もまたin vivoでMMPとTIMP遺伝子発現の調節にたずさわって いるかも知れないことを示している。

Key Words: connective tissue/metalloproteinases/collagenase/TIMP/growth factor

\section{A. Introduction}

The connective tissue matrix enmeshing cells is composed of extracellular matrix molecules including collagens, elastin, acidic glycoproteins, and proteoglycans. The varied structural and functional characteristics of different connective tissues are reflected, in part, by differences in the composition of the constituent macromolecules. Although most matrix components contribute to the physical characteristics of connective tissues, the collagen fibres, through their tensile strength, are particularly important in providing structural stability. To date, 14 collagen types have been recognized and characterized to varying degrees(reviewed by Burgeson, 1988), but all collagen types contain one or more regions in which the three constituent $\alpha$-chains form a triple helical collagen fold that is highly resistant to proteolysis. However, despite the important consequences of connective tissue destruction in pathology and normal tissue turnover, the mechanisms of connective tissue degradation, the proteinases involved, and their cellular sources are not well understood(Sodek and Overall, 1988).

Several homologous matrix degrading neutral metalloendoproteinases, termed matrix metalloproteinases(MMPs), are thought to participate in the degradation of the extracellular matrix and are secreted by resident tissue cells and infiltrating

\section{A. 序 論}

細胞の周囲をとり囲んでいる結合組織マトリックスは、コ ラーゲン、エラスチン、酸性糖タンパク、プロテオグリカンな どの細胞外マトリックス分子で構成されている。異なる䊅合組 織が示す構造的、機能的性質の違いは、それを構成している高 分子の組成の違いを少くとも一部は反映している。多くのマト リックス成分が結合組織の物性的性質に関わっているが、強い 張力をもつコラーゲン線維は、構造を安定化させるのに特に重 要な㗢きをしている。今日まで14の型のコラーゲンが見出さ れ、性質が調べられている(Burgesonによる総説、1988)。全て の型のコラーゲンには、構成している3本の $\alpha$-鎖が互いに巻い て三重らせん鎖を形成し、そのためにタンパク分解に対して抵 抗性が極めて高い領域が1つ又は、それ以上存在する。しかしな がら、正常な組織の代謝や病気の時の䊅合組織の破壊は、重要 な影響を与えるにも関わらず、䊅合組織分解のメカニズム、分 解に関与しているプロテアーゼ類、さらにそれらを分必する細 胞などについては充分に判っていない(SodekとOverall, 1988)。

マトリックス金属タンパク分解醭素(MMPs)と名付けられ た数種の互いによく似た構造をもつ中性のマトリックス分解酵 素が、細胞外マトリックスの分解にたずさわっていると考えら れている。そしてそれらの酳素は、組織の細胞や炎症時の炎症 細胞によって分泌される(表 1)。この総説では、MMPsとその阻 
inflammatory cells(Table I). This review will focus on the structure, characteristics, and regulation of MMPs and their inhibitors.

\section{B. Types of MMPs}

\section{B-1. The Collagenases}

Latent interstitial collagenase(MMP-1) is present as two forms having $M_{r} s$ of 57,000 and a 52,000 that, on activation, convert to 47- and 42-kD active enzymes, respectively (Stricklin et al., 1977, 1978). The two $M_{r}$ species differ only by the presence of $N$-linked oligosaccharide chains in the higher $\mathbf{M}_{r}$ species(Nagase et al., 1981, 1983; Wilhelm et al., 1986; Goldberg et al., 1986). Interstitial collagenase is synthesized by a variety of cells including fibroblasts, chondrocytes, endothelial cells, keratinocytes, and macrophages. Leukocyte collagenase(MMP-8) is released from storage granules in polymorphonuclear leukocytes(Hasty et al., 1984; 1986), but although the enzyme cleaves the identical scissile bonds in collagens as interstitial collagenase, it has a different $M_{r}(75-k D)$, substrate kinetics(Hasty et al., 1987), and antigenic properties (Hasty et al., 1984).

\section{B-2. The Gelatinases/Type IV Collagenases}

Two forms of gelatinase that efficiently degrade dena-
害物質の構造、性質、調節に焦点をあてようと思う。

\section{B. MMPsの種類}

\section{B-1.コラゲナーゼ}

潜在型間質コラゲナーゼ(MMP-1)には分子量が57,000と 52,000である 2 種の䣼素が存在し、それらは活性化されて、そ れぞれ47 kD及び42 kDの活性型酵素に変る(Stricklin ら, 1977, 1978)。この2種類の酵素の違いは、N-䊅合型オリゴ糖が大きい 方の分子についているという点のみである(Nagase ら，1981, 1983; Wilhelm 5, 1986; Goldberg 5, 1986)。間質コラゲナーゼは 線維芽細胞、軟骨細胞、内皮細胞、ケラチン細胞、マクロファ ージなど多種の細胞が産生している。白血球のコラゲナーゼ (MMP-8)は、多形核白血球の貯蔵顆粒から分泌される(Hastyら, 1984; 1986)。この醳素のコラーゲンの切断部位は間質コラゲナ 一ゼと同じであるが、分子量 $(75 \mathrm{kD})$ 、基質の反応速度論的解析 (Hasty 5, 1987)、抗原性(Hasty 5, 1984)が異なっている。

\section{B-2. ゼラチナーゼ/N型コラゲナーゼ}

変性コラーゲンの $\alpha$ 鎖(ゼラチン)と V 型コラーゲンの未变 性の三重らせん鎖部位を効率よく分解する 2 種類のゼラチナー ゼが報告されている。72 kDaゼラチナーゼ（MMP-2）は䊅合組 織細胞(Murphy ら, 1981; Collier ら, 1988)と腫瘍細胞から分泌さ

Table I The Matrix metalloproteinase family

\begin{tabular}{|c|c|c|}
\hline Name & $\mathrm{M}_{\mathrm{r}}^{1}$ & Substrates \\
\hline $\begin{array}{l}\text { Interstitial collagenase } \\
\text { MMP-1 }\end{array}$ & $\begin{array}{l}52,000 \\
57,000^{*}\end{array}$ & $\begin{array}{l}\text { I, II, III, VII, X collagens, } \\
\text { casein }\end{array}$ \\
\hline $\begin{array}{l}\text { Leukocyte collagenase } \\
\text { MMP-8 }\end{array}$ & $70-75,000$ & I, II, III collagens, casein \\
\hline $\begin{array}{l}\text { 72-kD gelatinase/type IV collagenase } \\
\text { MMP-2 }\end{array}$ & $70-72,000$ & $\begin{array}{l}\text { IV, V, VII, XI collagens, } \\
\text { gelatins, fibronectin, elastin }\end{array}$ \\
\hline $\begin{array}{l}\text { 92-kD gelatinase/type IV collagenase } \\
\text { MMP-9 }\end{array}$ & $92,000^{*}$ & $\begin{array}{l}\text { V, IV, VII collagens, } \\
\text { gelatins, elastin }\end{array}$ \\
\hline $\begin{array}{l}\text { Stromelysin } \\
\text { MMP-3 }\end{array}$ & $\begin{array}{l}57,000 \\
60,000^{*}\end{array}$ & $\begin{array}{l}\text { proteoglycan core protein, } \\
\text { laminin, fibronectin, type I collagen }\end{array}$ \\
\hline $\begin{array}{l}\text { Stromelysin-2 } \\
\text { MMP-10 }\end{array}$ & & $\begin{array}{l}N \text {-propeptide, type IV, } \mathrm{V}, \mathrm{IX} \text { collagens, } \\
\text { gelatins, elastin, activates procollagenase }\end{array}$ \\
\hline $\begin{array}{l}\text { Stromelysin-3 } \\
\text { MMP-11 }\end{array}$ & 53,000 & $\begin{array}{l}\text { fibronectin, gelatins, } \\
\text { type II, IV, V collagens }\end{array}$ \\
\hline $\begin{array}{l}\text { PUMP-1 } \\
\text { MMP-7 }\end{array}$ & 28,000 & $\begin{array}{l}\text { gelatins, fibronectin, } \\
\text { proteoglycan core protein, transferrin }\end{array}$ \\
\hline \multicolumn{3}{|l|}{ Telopeptidase } \\
\hline MMP-4 & 35,000 & collagen C-propeptide \\
\hline
\end{tabular}

1 The $M_{r}$ of the latent human MMPs were determined by electrophoresis under reduced conditions.

* $\mathrm{M}_{\mathrm{r}}$ of glycosylated forms of the MMPs. 
tured collagen $\alpha$-chains (gelatin) and type IV collagen in the native triple helical region have been described. The $72-\mathrm{kD}$ gelatinase(MMP-2) is secreted by connective tissue cells (Murphy et al., 1981; Collier et al., 1988) and tumor cells and closely resembles the larger $92-\mathrm{kD}$ gelatinase secreted by polymorphonuclear leukocytes, monocytes, and macrophages (Murphy et al., 1982; Mainardi et al., 1984) and some transformed cells(Wilhelm et al., 1989). Although the 72-kD and 92-kD gelatinases are immunologically distinct, they are similar in that they both contain a fibronectin-like collagen binding domain(Fig.1). Unlike the $72-\mathrm{kD}$ gelatinase, the $92-\mathrm{kD}$ gelatinase is glycosylated and contains a 53-amino acid sequence that shows some similarity with a segment of the $\alpha 2(\mathrm{~V})$ collagen chain (Collier et al., 1988; Wilhelm et al., 1989).

\section{B-3. The Stromelysins}

Stromelysin occurs both as an unglycosylated $57-\mathrm{kD}$ protein and as a minor $60-\mathrm{kD} N$-linked glycosylated protein (Wilhelm et al., 1987; Okada et al., 1988). Stromelysin has a wide substrate specificity(Table I), which includes proteoglycan core protein and fibronectin and can also degrade basement membrane components including the nonhelical regions of type IV collagen and the laminin A chain. Three additional stromelysin-like MMPs(stromelysin-2, -3, and PUMP-1) have recently been identified by cDNA cloning(Breathnach $e t$ al., 1987; Muller et al., 1988). PUMP-1(putative metallopro-

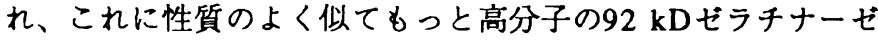
は、多形核白血球、単球、マクロファージ(Murphy 5、1982; Mainardiら，1984)、およびある種の形質転换細胞(Wilhelm ら， 1989)が分泌する。72 kD及び $92 \mathrm{kD} ゙$ ラチナーゼは免疫学的には 異なるが、どちらもフィブロネクチン様コラーゲン桔合ドメイ ンを持つという点では共通している(図 1)。72 kDゼラチナーゼ とは違って $92 \mathrm{kD} ゙$ ラナーゼには糖鎖がついていて、さらに $\alpha$ 2(V)コラーゲン鎖の一部と類似した53アミノ酸配列がある(Collier 5, 1988; Wilhelm 5, 1989)。

B-3. ストロムライシン

ストロムライシンは大部分が楉のつかない $57 \mathrm{kD}$ タンバク で、そのほかに少量の $60 \mathrm{kD}$ のN-䊅合型糖タンパクが見出されて いる(Wilhelm 5, 1987; Okada 5, 1988)。ストロムライシンはブロ テオグリカンのコアタンバクやフィブロネクチンなどを分解 し、基質特異性は広い(表 1)。さらに N 型コラーゲンの三重ら せん鎖以外の領域や、ラミニンの $\mathrm{A}$ 鎖などの基底膜成分を分解 出来る。ストロムライシンによく似た 3 種のMMPs(ストロムラ イシン-2、-3、およびパンプ1)が、最近CDNAのクローニング によって確認された(Breathnach5, 1987; Muller 5, 1988)。パン プ1(推定上のメタロプロテアーゼ1)は、ストロムライシンのN末領域に49\%類似し、C末領域のへモペキシン様ドメインの欠 如した短いMMP(267アミノ酸)である(Mullerら，1988)。パンプ 1 とストロムライシンはプロコラゲナーゼを活性化することが

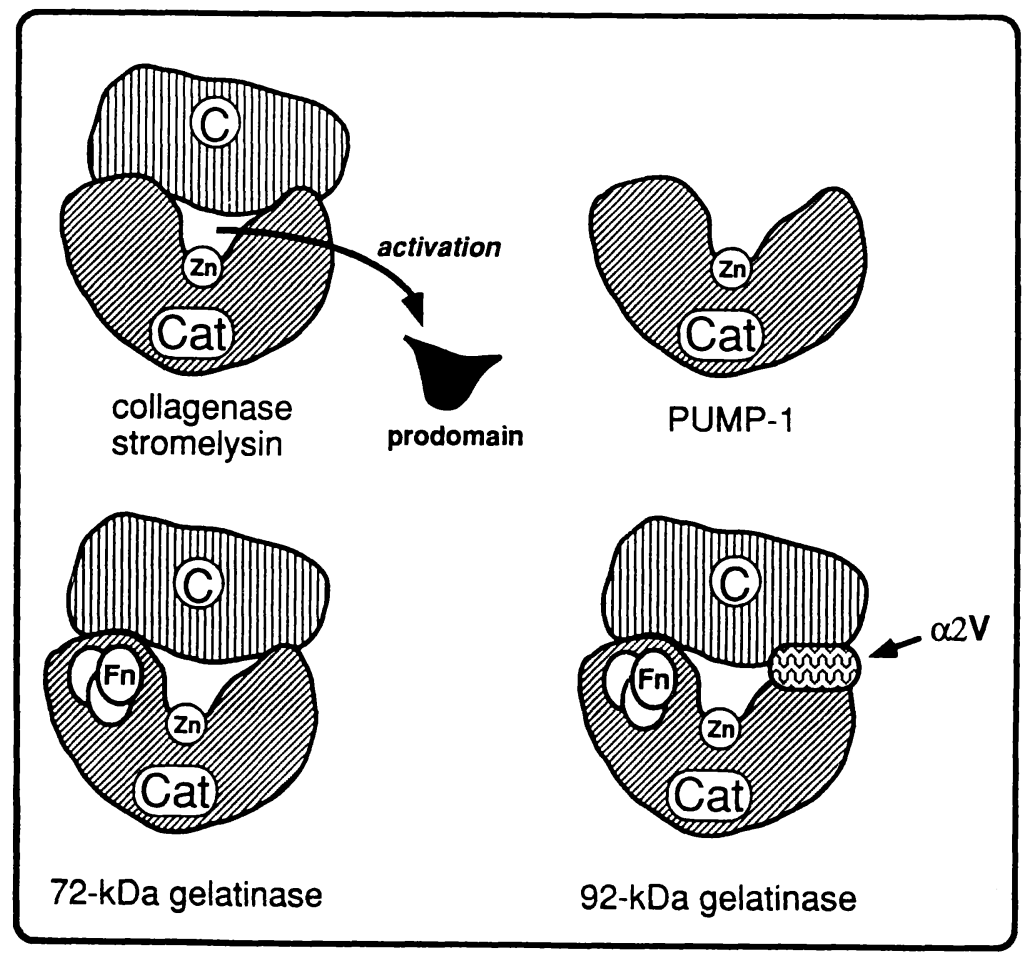

Fig. 1. Schematic representation of MMP mosaic structure. Proteinases are represented as globular domains in the active form after removal of the $\mathrm{N}$-terminal pro-domain. C, C-terminal hemopexin-like domain; $\mathrm{Zn}, \mathrm{Zn}^{2+}$ ion in MMP active site (white cleft); CAT, catalytic domain; Fn, fibronectin type II motif-like domain; $\alpha 2 \mathrm{~V}, \alpha 2$ type V collagen-like domain. 
teinase-1) is a truncated MMP(267-amino acids) that is $49 \%$ similar to the $\mathrm{N}$-terminal region of stromelysin, but it lacks the C-terminal hemopexin-like domain(Muller et al., 1988). PUMP-1 and stromelysin can activate procollagenase(Murphy et al., 1987; Ito and Nagase, 1988).

\section{Domain Structure of MMPs}

\section{C-1. The Amino-terminal 'Pro'domain}

Sequence analysis has revealed that the MMPs are structurally related, with conserved regions of significant homology. MMPs have a 17-19-amino-acid residue $\mathrm{N}$-terminal leader sequence, rich in hydrophobic amino acid residues, that is proteolytically removed after insertion of the nascent protein into the endoplasmic reticulum. The $\sim 180$-amino-acid residue $\mathrm{N}$ terminal region of the MMPs forms the propeptide, its site of cleavage from the protein core, and a segment containing the $N$ linked glycosylation sites. The prodomain is typically $\sim 80$ amino acid residues in length and contains a highly conserved sequence, PRCGVPDV, in which is located an unpaired cysteine residue. In the latent enzyme this cysteine is thought to coordinate with the $\mathrm{Zn}^{++}$ion in the active site, thus blocking the catalytic activity of the enzyme(see below).

\section{C-2. The Metal Ion Binding Catalytic Domain}

The MMPs are metal-dependent proteinases, requiring a $\mathrm{Zn}^{++}$ion for catalysis and $\mathrm{Ca}^{++}$ions for stability and full activity. Collagenase contains a region of 110 amino acids that is $25.5 \%$ identical to the zinc-binding region of the Serratia metalloproteinase(McKerrow, 1987). Moreover, within this sequence lies a stretch of 11 amino acids, HELGHSLGLSH, nine of which are identical and two are chemically similar to the putative zinc-binding site in the Serratia proteinase (McKerrow, 1987). The catalytic $\mathrm{Zn}^{++}$ion is complexed with three amino acid residues, the fourth coordination site being occupied by a water molecule in the active enzyme that is essential for catalysis.

\section{C-3. The Carboxyl-Terminal Hemopexin-Like Domain}

The 192-amino-acid C-terminal domain is less well conserved than the other domains, it is present in all MMPs except PUMP-1, and it appears to be involved in conferring substrate specificity to the MMPs and is involved in TIMP binding. Interestingly, the C-terminal is $\sim 20 \%$ identical with the heme-binding serum protein hemopexin(Matrisian et al., 1986) and contains four short(38-amino-acid residue) stretches that show a high degree of homology with complement S-protein/vitronectin. Of note, these motifs include part of the glycosaminoglycan- and heparin-binding sites of S-protein which may account for the binding of collagenase and MMP-2 to heparin.

\section{C-4. Extracellular Matrix-Like Domains}

The 72-kD and 92-kD gelatinases are distinguished from the other MMPs by the presence of extra amino acid se-
出来る(Murphyら, 1987; Ito と Nagase, 1988)。

\section{MMPsのドメイン䊔造}

\section{C-1.アミノ末端“前駆体”ドメイン}

配列分析からMMPsは、非常によく似た領域が保存された 構造上関係の深い酵素群であることが明らかとなった。 MMPs には、疎水性アミノ酸に富む17〜19アミノ酸残基のN-末のリー ター配列があり、これは小胞体に合成されたばかりのタンバク が入りこんだ後にタンパク分解されて除かれる。約180アミノ酸 残基からなるMMPsの N末部分は前駆体ペプチドを形成し、そ こでタンパクコアからの切断が行なわれる。この部分には館の 䊅合するアスパラギンが存在する。前駆体ドメインは、約 80 ア ミノ酸残基の長さで、相手のないシステイン残基を含む PRCGVPDVという配列が保持されている。潜在型醅素では、こ のシステインは $\mathrm{Zn}^{++}$と共役していて、その為に触媒活性が妨げ られていると考えられている(後述)。

\section{C-2. 金属イオン結合触媒ドメイン}

MMPsは触媒反応の為に $\mathrm{Zn}^{++}$イオンを必要とし、安定性と 十分な活性発揮のためにCa+1イオンを必要とする金属依存性酵 素群である。コラゲナーゼのこの領域は110アミノ酸残基からな ク、これはSerratiaの金属タンパク分解酳素の亜鉛結合領域と 25.5\%同じである(McKerrow, 1987)。さらにこの配列の中には、 HELGHSLGLSHというアミノ酸11個の配列があり、このうち 9 アミノ酸は、Serratiaのタンパク分解酵素の恐らく亜鉛䊅合部位 と思われる配列と全く同一で、残りの 2 残基も化学的性質の上 く似たアミノ酸である(McKerrow, 1987)。触媒中心のZn+1イオン は、活性酵素中の 3 個のアミノ酸と䊅合し、第 4 番目の共役部 位は水分子に占められるということが触媒反応には必須であ る。

\section{C-3. C末のへモペキシン様ドメイン}

約192アミノ酸からなるC-末ドメインは他のドメイン程保 存されていないが、パンプ 1 以外の全てのMMPsに存在する。 そしてこのドメインがMMPsの基質特異性を決めているらしい し、またTIMPとの結合に関与している。面白いことには、C末 はへム䊅合血清タンパクであるへモペキシンと約20\%同じ棈造 をしていて(Matrisianら, 1986)、補体Sタンパク/ビトロネクチ ンと高い相同性をもつ短い(38アミノ酸残基)配列を 4 個含んて いる。注目す心゙きは、これらのモチーフは Sタンパクのグリコ サミノグリカン結合部位及びヘパリン䊅合部位の一部を含むこ とで、それがコラゲナーゼやMMPsがヘバリンに䊅合するのに 役立っているらしい。

\section{C-4. 細胞外マトリックス様ドメイン}

他のMMPsと違って、 $72 \mathrm{kD}$ 及び $92 \mathrm{kD} ゙$ テチナーゼには触 媒ドメインのすぐ隣に余分のアミノ酸配列が存在する(Collier ら, 1988; Wilhelmら, 1989)。どちらのぜラチナーゼにも、触媒 ドメインの $\mathrm{N}$ 末側に58アミノ酸残基からなるフィブロネクチン 様 I 型コラーゲン結合モチーフが 3 回繰り返されて存在してい 
quences lying adjacent to the catalytic domain(Collier $e t$ al., 1988; Wilhelm et al., 1989). Both gelatinases contain three copies of a 58-amino acid residue fibronectin-like type II collagen binding motif lying $\mathrm{N}$-terminal to the catalytic site. This 175-amino-acid region is thought to be involved in the high affinity binding of these MMPs to gelatin.

In addition to the fibronectin-like region, the $92-\mathrm{kD}$ gelatinase, but not the 72-kD gelatinase, contains a 53-amino-acid proline rich sequence located C-terminal to the $\mathrm{Zn}^{++}$-binding domain. This region is $42 \%$ identical to a segment of the $\alpha 2(\mathrm{~V})$ collagen chain and may be a structural motif involved in intermolecular interactions that form a collagen fold, linking 92-kD gelatinase dimers and trimers. 92-kD gelatinase also has significant type $\mathrm{V}$ collagenolytic activity, a function in which this domain may participate.

\section{Zymogen Form and Activation}

MMPs are secreted as latent inactive proenzymes that must be first activated for proteolytic activity. Although sequence comparisons between the MMPs that have been cloned has provided some insights into the biochemical nature and physiological mechanisms of activation, the nature of MMP latency and activation is still incompletely understood. MMPs can be activated by a variety of reagents and methods in vitro including treatment with organomercurials(eg. p-aminophenylmercuric acetate, APMA)(Sellers and Reynolds, 1977; Stricklin et al., 1983; Springman et al., 1990), chaotropic ions (Abe and Nagai, 1972; Springman et al., 1990), proteolytic cleavage by trypsin and plasmin (Vaes 1972; Bauer et al., 1975; O'Grady et al., 1981; Okada et al., 1988), detergents(BirkedalHansen and Taylor, 1982), and $\mathrm{Au}(\mathrm{I})$ salts (Lindy et al., 1986).

In both the glycosylated $(57 \mathrm{kD})$ and the nonglycosylated(52 kD) forms of collagenase, cleavage of the $N$-terminal propeptide from the protein core occurs at one of three peptide bonds within the sequence QFVL at the boundary between the prodomain and the rest of the molecule. However, the organomercurial, APMA, is incapable of peptide bond scission and an $\mathrm{N}$-terminal valine is inconsistent with the specificity of trypsin. Thus, it is thought that the initial reaction product of trypsin and APMA-activated MMPs is unstable and autolytic cleavage of the propeptide then occurs to generate a more stable, active form of the enzyme. In most MMPs, this results in an $\sim 10 \mathrm{kD}$ loss in $\mathrm{M}_{\mathrm{r}}$, but the actual decrease in $\mathrm{M}_{\mathrm{r}}$ is dependent on the MMP. However, it remains to be resolved whether the final activation step of MMPs is indeed the result of autocatalysis, as shown for collagenase, or through the activity of activation intermediates, as shown for stromelysin (see below).

The highly conserved sequence, PRCGVPDV, immediately precedes the $N$-terminus of the cleaved and activated MMPs except in MMP-9, where the PRCGVPD element occurs C-terminal to the $\mathrm{Met}_{94}$ activation cleavage site (Wilhelm
る。この175アミノ酸残基の作る領域は、これらのMMPsがゼラ チンに強く䊅合するのに関係しているのであろう。

フィブロネチン様領域以外に、92 kDゼラチナーゼには $\mathrm{Zn}^{++}$䊅合ドメインのC末側に53個のアミノ酸からなるプロリン

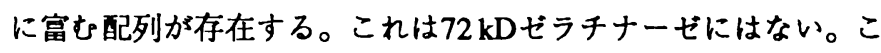
の領域は $\alpha 2(\mathrm{~V})$ コラーゲン鎖の一部と $42 \%$ の相同性を示した。 この領域は分子間䊅合に関与した構造モチーフで、この分子間 䊅合により92kDゼラチナーゼ二量体や三量体がつながってコラ ゲナーゼ様おりたたみ構造を形成するのであろうか。92kDゼラ チナーゼはV型コラーゲンを分解する活性も持っており、これ にはこのドメインが関与しているのであろう。

\section{D. プロ䤃素と活性化}

MMPsは潜在型䣼素、つまりまた不活性のプロ酳素として 分泌されるので、まず最初にタンバク分解をうけて活性化され なければならない。クローニングされたMMPs間の配列の比較 から活性化について生化学的性質や生理的機棈がある程度判っ てきたが、MMPsの潜在性と活性化はまだ完全には解明されて いない。MMPsはin vitroでは、有機水銀(例えば、バラアミ) フェニル水銀一酢酸、APMA)(SellersとReynolds, 1977; Stricklin 5, 1983; Springman 5, 1990)、カオトロピックイオン(Abeと Nagai, 1972; Springman 5, 1990)、トリブシンやプラスミンによ ろタンバク分解(Vaes, 1972; Bauer ら, 1975; O'Grady 5, 1981; Okada 5，1988)、界面活性㓮(Brickedal-Hansen と Taylor, 1982)、 $\mathrm{Au}(\mathrm{I})$ 塩(Lindy 5, 1986)など多くの試薬や方法によって活性化さ れる。

コラゲナーゼでは、榶のついている型 $(57 \mathrm{kD})$ もいていな い型(52kD)のどちらでも、前駆体ドメインと残りの分子の境界 にあるQFVLという配列内の 3 ペプチド䊅合のうちの1つで、 $\mathrm{N} 末$ 前駆体ペプチドが残りの部分から切断される。しかし、 有機水銀であるAPMAがペプチド䊅合を切ることは不可能であ るし、N末のバリンで切れることはトリブシンの特異性と適合 しない。従って、トリプシンやAPMAで活性化されて最初に出 来る反応生成物は不安定で、続いて自己分解が起こってょり安 定な活性型酳素が生成されると考えられている。この䊅果、 MMPsの多くで分子量として約 $10 \mathrm{kD}$ が失われるがその分子量の 減少量はMMPによって異なっている。しかしながら、MMPsの 活性化の最終段階が本当にコラゲナーゼにみられるような自己 触媒の䊅果なのか、ストロムライシンにみられるように(後述) 活性をもつ活性化中間体を通っていくものなのか、解明される べき問題が残されている。

高度に保存されているPRCGVPDVという配列は、切断さ れて活性化されたMMPsのN末のすぐ上流にある。MMP-9では 例外的に、PRCGVPD配列は活性化切断部位であるMet94よりC 末側にある(Wilhelm 5, 1989)。PRCGVPDV配列中にあるシステ イン残基は対(S-S結合)をつくらずに、水分子と置きかわって触 媒中心の $\mathrm{Zn}^{++}$イオンと共役し、このため醅素を不活性化してい 
et al., 1989). The cysteine residue found in the PRCGVPDV element is unpaired and coordinates with the catalytic $\mathrm{Zn}^{\text {++ }}$ ion, displacing a water molecule, thus rendering the enzyme inactive. Activation by sulphydryl-modifying reagents in vitro occurs when this cysteine residue is transiently dissociated from the $\mathrm{Zn}^{++}$and reacts with the modifying reagent, thereby preventing reassociation of the cysteine with the $\mathrm{Zn}^{++}$ion (Springman et al., 1990). Likewise, proteolytic cleavage within the prodomain, the use of sodium dodecyl sulphate and chaotropic agents may also displace the cysteine residue, exposing the $\mathrm{Zn}^{++}$ion to the solvent and activating the enzyme (Van Wart and Birkedal-Hansen, 1990).

\section{D-1. Stromelysin/Procollagenase Activator}

'Procollagenase activators' that can either react with procollagenase nonproteolytically(Tyree $e t$ al., 1981; Vater et al., 1983,1986 ) or proteolytically(Ishibashi et al., 1987) appear essential for full collagenase activation. Without the procollagenase activator, collagenase is not activated even though both trypsin and APMA produce a decrease in the $M_{r}$ of the collagenase(Vater et al., 1983, 1986). The cDNA of rabbit and human synovial procollagenase activators have been cloned (Fini et al., 1987; Okada et al., 1986) and identified as stromelysin.

The mechanism of action of stromelysin as a collagenase activator is not clear, but it appears that stromelysin produces a small decrease in the $M_{r}$ of collagenase that markedly enhances the specific activity of the enzyme(Murphy et al., 1987; He et al., 1989). Although stromelysin does not efficiently activate procollagenase, activated stromelysin does reduce the $\mathrm{M}_{\mathrm{r}}$ of plasmin- or trypsin-activated collagenase from $42 \mathrm{kD}$ by $\sim 2 \mathrm{kD}$ through the removal of the C-terminal $\sim 15$ amino acid residues. This cleavage "superactivates" the enzyme with a 5- to 8-fold increase in specific activity.

\section{E. MMP Inhibitors}

\section{E-1. TIMP}

Activated MMPs are inhibited by a number of inhibitors, the most extensively characterized is TIMP, the tisue inhibitor of MMPs. Recently, additional members of the TIMP family have been identified and characterized to various degrees. MMPs are also inhibited by $\alpha_{2}$-macroglobulin(Abe and Nagai, 1972; Sottrup-Jensen and Birkedal-Hansen, 1989) and a low $\mathrm{M}_{\mathrm{r}}$ cationic inhibitor present in cartilage(Kuettner $e t$ al., 1976; Horton et al., 1978). However, recent attempts at isolating this low $\mathrm{M}_{\mathrm{r}}$ inhibitor have not been successful in confirming the presence of a unique inhibitor, distinct from the TIMPs.

The cDNA for human TIMP has been cloned(Docherty et al., 1985; Carmichael et al., 1986). TIMP is synthesized by many tissue cells(Vater et al., 1979; Murphy et al., 1977; Pettigrew et al., 1980, Cawston et al., 1981, Welgus and Stricklin, 1983 ) and has been isolated from amniotic fluid(Murphy $e t$ al.,
る。SH試薬によるin vitroでの活性化は、このシステインが $\mathrm{Zn}^{++}$ から一時的に外されて修飾試薬と反応し、そのためにシステイ ンと $\mathrm{Zn}^{++}$イオンの再䊅合が妨げられる時におこる(Springmanら， 1990)。同様に前駆体ドメイン内でのタンバク分解や、ドデシル 硫酸ナトリウムやカオトロビック試䒱の使用も、同様にシステ イン残基を置换して $\mathrm{Zn}^{++}$イオンを溶媒にさらし䤃素を活性化し ているのであろう(Van WartとBirkedal-Hansen, 1990)。

\section{D-1．ストロムライシン/ブロコラゲナーゼ活性化物公}

'プロコラゲナーゼ活性化物質'は、プロコラゲナーぜを夕 ンパク分解しないもの(Tyree 5, 1981; Vaterら,1983, 1986)であっ ても、するもの(Ishibashi ら, 1987)であっても、コラゲナーぜを 完全に活性化するのに必須であるようにみえる。プロコラゲナ 一ゼ活性化物質なしには、コラゲナーゼの分子量がたとえトリ プシンとAPMAによって減少しても、コラゲナーゼは活性化さ れないのである(Vaterら, 1983, 1986)。ウサギとヒトの滑膜のブ ロコラゲナーゼ活性化物質のcDNAがクローニングされ(Finiら， 1987;Okada5,1986)、それがストロムライシンであることが確 認された。

コラゲナーゼ活性化物質としてのストロムライシンの作用 機構は明らかではないが、ストロムライシンによるコラゲナー ゼの分子量の減少は小さいけれども、これにより醭素活性は著 しく增大する(Murphy5, 1987; He 5, 1989)。ストロムライシン はプロコラゲナーゼを効率よく活性化できないが、活性化され たストロムライシンはプラスミンやトリブシンで活性化した 42

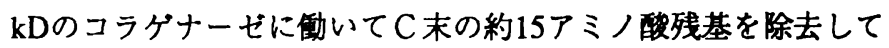
約 $2 \mathrm{kD}$ 減少させる。この切断により醭素はさらに活性化され、 比活性は5 8倍上昇する。

\section{E. MMP阻害剂}

\section{E-1. TIMP}

活性化されたMMPsは多くの阻害物質で阻害をうける。そ の中で最もよく調べられているのは組織中に存在するMMPs阻 害物質であるTIMPである。最近、TIMP族の新らしいメンバー の存在が確認され、ある程度まで性質が調べられている。 MMPsは、 $\alpha$ 2マクログロブリン(AbeとNagai, 1972; SottrupJensen と Birkedal-Hansen, 1989)や、軟骨に存在する低分子の暒 オン性阻害剂(Kuettner ら, 1976; Hortonら，1978)によっても阻害 される。しかし最近この低分子阻害物質の単離が試みられたが TIMPとは異なる新らしい阻害物質の存在を確かめることには成 功しなかった。

ヒトTIMPのcDNAはクローニングされている(Dockertyら， 1985;Carmichaelら, 1986)。TIMPは桨くの組織細胞で合成されて いる(Vater 5, 1979; Murphy 5, 1977; Pettigrew ら, 1980; Cawton 5. 1981; Welgus $\measuredangle$ Stricklin, 1983) し、羊水(Murphy 5,1981 ; Welgus とStricklin, 1983)、血清(Welgus と Stricklin, 1983)、唾液(Drouin ら, 1988)からも単離されている。また血小板(Cooper ら, 1985)や マクロファージ(Welgusら, 1985)の分泌物としても確認されてい 
1981; Welgus and Stricklin, 1983), serum(Welgus and Stricklin, 1983), saliva(Drouin et al., 1988), and identified as a secretory product of platelets(Cooper $e t$ al., 1985) and macrophages (Welgus et al., 1985). TIMP specifically blocks the activity of all MMPs investigated by forming an essentially irreversible, 1:1 stoichiometric complex with the activated MMPs(Fig.2) (Welgus et al., 1979; Cawston et al., 1981, 1983), the $\mathrm{K}_{\mathrm{D}}$ having been determined for active collagenase to be $1.4 \times 10^{-10} \mathrm{M}$ (Welgus et al., 1985). Thus, the TIMP to MMP balance is critical in determining the net level of MMP activity. TIMP has no effect on the activity of other proteinases, including the bacterial collagenases, thermolysin, and serine, thiol, and aspartic proteinases.

The 184-amino-acid TIMP core protein has a predicted $M_{r}$ of 20,685 and contains two potential $N$-glycosylation sites, both of which appear to be utilized(Stricklin 1986; Carmichael et al., 1986), to give the mature secreted product an $M_{r}$ of $\sim 28.5$ $\mathrm{kD}$. However, neither of the $N$-linked oligosaccharide chains appears to be essential for inhibitory activity(Murphy et al., 1985; Stricklin 1986). TIMP contains six disulphide bonds and is highly resistant to $\mathrm{pH}$ and temperature extremes(Welgus $e t$ al., 1979; Cawston et al., 1980, 1981). It was initially thought that TIMP was sensitive to APMA and trypsin. However, when highly purified TIMP and collagenase were prepared, Cawston et al.(1983) found that TIMP was resistant to APMA and trypsin; that TIMP/collagenase complexes could not be chromato-
る。TIMPはいままで調べられた全てのMMPsの活性を、活性型 MMPs と化学量論的に1:1の不可逆的な複合体を形成して特異的 に阻害する(図2)(Welgus 5, 1979; Cawston 5, 1981, 1983)。活性 型コラゲナーゼに対する KDは $1.4 \times 10^{-10} \mathrm{M}$ と算定されている (Welgusら, 1985)。このようにMMPにたいするTIMPの量比は、 MMP活性の強さを決める上で決定的に重要である。TIMPは、 細菌のコラゲナーゼ、サーモライシン、セリンー、チオールー およびアスパラギンータンパク分解酳素などの他のタンパク分 解酵素の活性に対しては阻害効果を示さない。

184個のアミノ酸からなるTIMPのコアタンパク部分は、分 子量が20,685と計算される。この中には榶のつき得るアスバラ ギンが2個あり、そのどちらにも糖がついているらしく(Stricklin, 1986; Carmichaelら，1986)、このため出来上がった分必産物 の分子量は䄪 $28.5 \mathrm{kDa}$ となる。かし、どちらのN-䊅合型桾鎖 も阻害活性には必須でないらいしい(Murphyら, 1985; Stricklin, 1986)。TIMPは 6 個のジスルフィド結合をもち、pHや温度の変 化に抵抗性が高い(Welgus 5, 1979; Cawston 5, 1980, 1981)。以前 は、TIMPはAPMAやトリプシンに感受性が高いと考えられてい た。しかし精製されたTIMPやコラゲナーゼが得られるように なって、TIMPがAPMAやトリプシンに抵抗性があり、TIMP／ コラゲナーゼ複合体はクロマトグラフィで解離させることが出 来ないこと、TIMP／コラーゲナーゼ複合体をAPMA、トリプシ ンやプラスミンで活性化することが出来ないことがCawstonら (1983)により見出された。

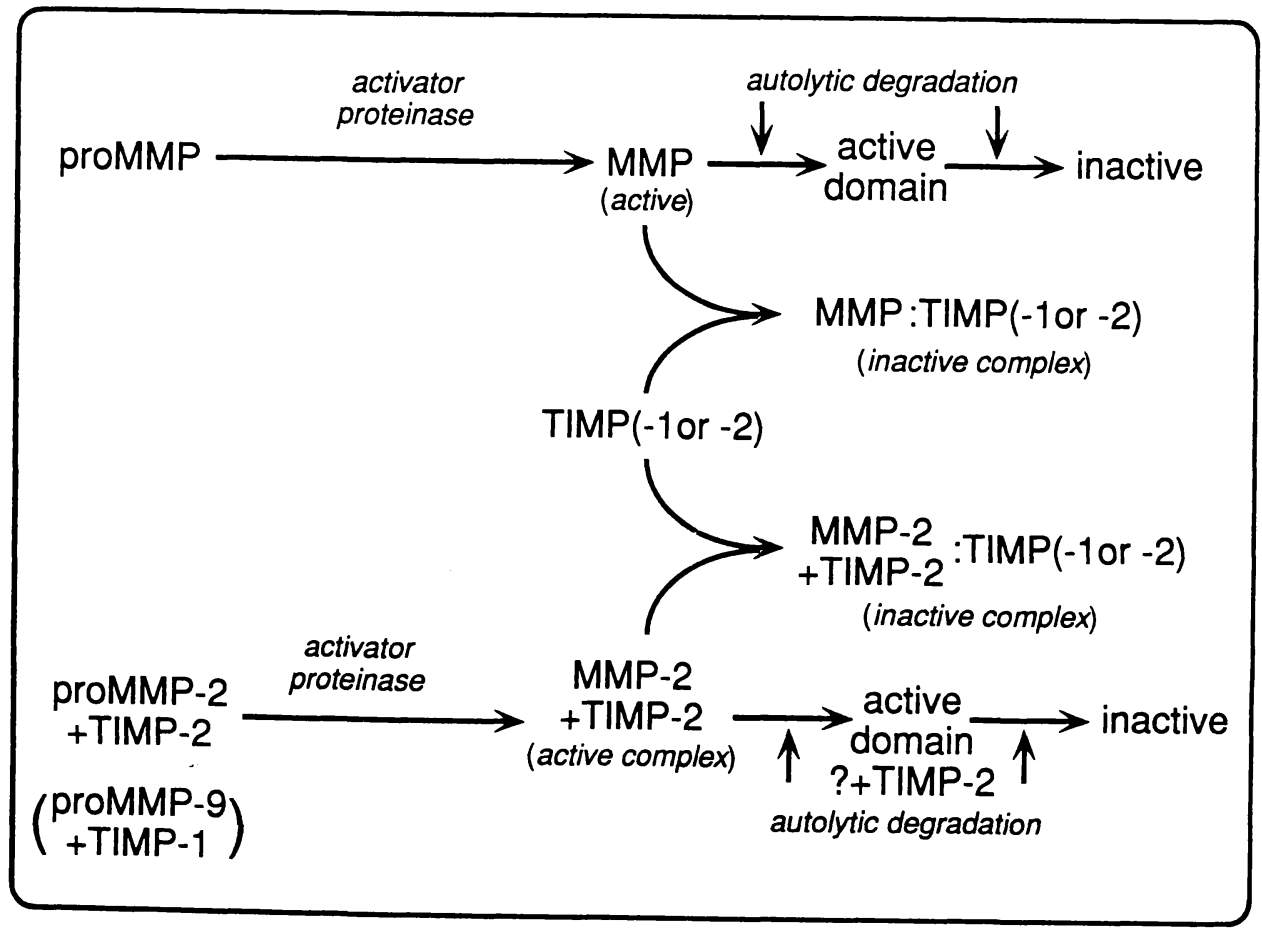

Fig. 2. Regulation of MMP activity by activators and TIMPs. proMMP, represents all MMPs except MMP-2 andMMP9. The activation of proMMP-2 and proMMP-9 are represented separately since these MMPs, in the latent form, can be complexed with either TIMP-2 or TIMP-1 as appropiate. The activation pathway for MMP-9 is thought to be similar to MMP-2 other than that MMP-9 complexes with TIMP-1(see text). 
graphically dissociated; and that TIMP/collagenase complexes could not be activated by APMA, trypsin, or plasmin.

\section{E-2. TIMP-2}

Recently, a number of other MMP inhibitors that are closely related to TIMP(-1) have been described. Reverse zymography and immunoabsorbance were used by Herron et al. (1986) to demonstrate the presence of three inhibitors of MMPs (IMPs) that were secreted by capillary endothelial cells. In addition to TIMP, two novel IMPs, IMP-1(M $22 \mathrm{kD}$, nonreduced) and IMP-2(M $19 \mathrm{kD}$, nonreduced) were identified, but not fully characterized. Three groups have reported the sequence and properties of a new MMP inhibitor, termed TIMP2 , that has different chromatographic properties, $M_{r}$, antigenicity, and $N$-terminal sequence to TIMP(Stetler-Stevenson $e t$ al., 1989; De Clerck et al., 1989; Goldberg et al., 1989). The cDNAs for human and bovine TIMP-2 were recently cloned (Boone et al., 1990; Stetler-Stevenson et al., 1990).

Human TIMP- 2 consists of 194 amino acid residues with a 26 -amino-acid residue leader sequence and shows $\sim 65 \%$ similarity and $\sim 38 \%$ identity with TIMP, but is not glycosylated. Importantly, the positions of the 12 cysteines and 3 of 4 tryptophan residues are conserved. Similar to TIMP, TIMP-2 inhibits active collagenase and active MMP-2 by forming an irreversible 1:1, noncovalent complex with the enzyme. TIMP-2 is also heat and $\mathrm{pH}$ stable, shows resistance to trypsin treatment, and loses activity following reduction and alkylation. The $M_{r}$ reported for human TIMP-2 is $21-24 \mathrm{kD}$ (Stetler-Stevenson et al., 1989; Goldberg et al., 1989).

A surprising property of TIMP-2 is that, in addition to the inhibition of active MMP-2, TIMP-2 forms noncovalent complexes with latent MMP-2 in a stoichiometric manner (Stetler-Stevenson et al., 1989; Goldberg et al., 1989). Thus, inhibition of one mole of active MMP-2 requires two moles of TIMP-2. Although it has been long known that TIMP does not form complexes with latent collagenase(Welgus et al., 1979) TIMP has recently been found to form noncovalent 1:1 molar ratio complexes with latent $92-\mathrm{kD}$ gelatinase(Goldberg et al., 1989; Wilhelm et al., 1989). The function and physiologic significance of TIMP and TIMP-2 bound to latent gelatinases is not clear. Goldberg et al.(1989) reported that TIMP-2, bound to latent MMP-2, did not have any apparent effects on the activation of MMP-2 with APMA or the activity of MMP-2 following APMA activation. However, 92-kD gelatinase that is free of TIMP is released from polymorphonuclear leukocytes and has been found to exhibit an $\sim 10$-fold higher gelatinolytic and type IV collagenolytic activity than when complexed with TIMP(Wilhelm et al., 1989). Similarly, in TIMP-2 depleted environments, such as that following Concanavalin $\mathrm{A}(\mathrm{ConA})$ stimulation of human fibroblasts(Overall and Sodek, 1990), a low $\mathrm{M}_{\mathrm{r}}(61-\mathrm{kD})$, high specific activity, activated form of $72-\mathrm{kD}$ gelatinase is produced. This indicates that TIMP-2 bound to the

\section{E-2. TIMP2}

最近TIMP(-1)とよく似た別のMMP阻害物質が数多く報告 されている。逆転ザイムグラフィと免疫吸収の方法を用いて、 Herronら(1986)は毛細血管内皮細胞が分泌する 3 種のMMPs阻害 物質(IMPs)の存在を示した。それらは、TIMP以外に 2 種の新ら しいIMPsで、IMP-1(分子量は非邉元で22 kD)とIMP-2(分子量は 非還元で19 kD)と確認されたが、まだ充分に性状が調べられて いない。クロマトグラフィ上での性質、分子量、抗原性、N末 の配列がTIMPとは異なる新らしいMMP阻害物質TIMP-2の構造 配列と性質が 3 つのグルーブから報告された(Stetler-Stevenson 5, 1989; De Clerck 5, 1989; Goldberg 5, 1989)。ヒトとウシの TIMP-2のcDNAが最近クローニングされた(Booneら,1990; Stetler-Stevenson 5,1990 )。

ヒトTIMP-2は194アミノ酸残基からなり、これに26アミノ 酸残基からなるリーダー配列がついていて、TIMP-2はTIMPと 約 $65 \%$ の類似性と約 $38 \%$ の相同性を示すが、榶はついていな い。重要な点としては、12個のシステインの位圈と4個のトリフ トファンのうち3個の位置が、TIMPと同じ位置に保存されてい ることがあげられる。TIMPと同样に、TIMP-2は活性化された コラゲナーゼやMMP-2を阻害するが、この際醭素と1:1の量比で 不可逆的な非共有䊅合による複合体を形成する。TIMP-2もまた 熱やpHに安定で、トリプシン処理にも抵抗性を示すが、還元お よびアルキル化によって阻害活性は失われる。ヒトTIMP-2の分 子量は21-24 kDと報告されている(Stetler-Stevenson ら, 1989; Goldberg 5, 1989)。

TIMP-2の驚くべき性質は、活性型MMP-2を阻害すること 以外に、TIMP-2は化学量論的方法で潜在型MMP-2 と非共有䊅合 で複合体を形成するということである(Stetler-Stevensonら, 1989; Goldberg 5, 1989)。従って、活性型MMP-2の1モルを阻害するの に2モルのTIMP-2が必要となる。長い間、TIMPについては潜在 型コラゲナーゼと複合体を形成しない(Welgusら, 1979)と考えら

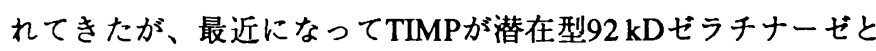
$1: 1$ の量比で非共有䊅合複合体を形成することが見出された (Goldberg 5, 1989; Wilhelm ら, 1989)。潜在型ゼラチナーゼに TIMPやTIMP-2が䊅合するいう機能や生理的意味は不明であ る。Goldberg 5(1989)は、潜在型MMP-2にTIMP-2が䊅合して も、APMAによるMMP-2の活性化や、APMAによる活性化に よって生じたMMP-2の活性に対して何ら影響を与えないと報告

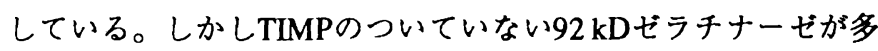
形核白血球から放出されるが、このゼラチン及びIV型コラーゲ ン分解活性はTIMPと複合体を形成している時と比較すると約 10 倍高いことが見出された(Wilhelm 5，1989)。同様に、ヒト線維 芽細胞をコンカナバリン A(conA)で刺激した時のようなTIMP-2 の久亡した環境においては、低分子の $(61 \mathrm{kD})$ 高い比活性をもっ た72 kDゼラチナーゼの活性型が産生される(OverallとSodek, 1990)。このことは、TIMP-2は潜在型酵素に䊅合していると立 体障害によりMMPの完全な活性化を妨げるのか、或いは完全に 
latent enzyme reduces enzymic activity either by preventing the complete activation of the MMP or by partially inhibiting the activity of the fully activated enzyme, perhaps by steric means.

\section{F. Regulation of MMP and TIMP expression \\ F-1. MMP and TIMP Induction}

Normally the constitutive expression of MMPs by cells is very low or absent. The degree of stimulation of MMPs by an inducing agent varies between cells and culture conditions and is dependent upon the basal level of expression, which is cell and tissue specific. Regardless of the constitutive level of expression, maximal induction of collagenase by the potent collagenase inducer 12-O-tetradecanoylphorbol-13-acetate (TPA) appears to be relatively constant, $\sim 3-7 \mu \mathrm{g} / 10^{6}$ cells $/ 24 \mathrm{~h}$, for cells derived from a variety of sources(Wilhelm et al., 1986). In contrast, the constitutive expression of TIMP is not high, but TIMP mRNA can nonetheless be demonstrated in various tissues. Embryonic tissues in general, but particularly those tissues undergoing matrix deposition and remodeling, such as intramembranous and endochondral bone, contain low but detectable amounts of the TIMP transcript(Nomura et al., 1989).

Studies on the regulation of TIMP have not been as extensive as studies on collagenase and stromelysin. TIMP gene expression is induced by serum, the growth factors EGF, PDGF, and FGF(Edwards et al., 1985, 1986; Gewert et al., 1987), and the tumor promoter TPA(Edwards et al., 1986; Murphy et al., 1985, Clark et al., 1985). However, the co-ordinate increase in both MMPs and TIMP by these stimuli appears contradictory to the achievement of a resorptive phenotype.

Transcription of MMP genes is up-regulated by a variety of biologically active agents. Oncogenic viruses and tumor promotors such as TPA, mitomycin, and UV light induce the expression of collagenase(Aggeler $e t$ al., 1984; Brinkerhoff $e t$ al., 1979; Murphy et al., 1985; Angel et al., 1986). Collagenase synthesis is also stimulated by cytokines and growth factors including IL-1(Murphy et al., 1985; Dayer et al., 1986; Richards and Rutherford, 1990), PDGF(Bauer et al., 1985; Chua et al., 1985), EGF(Chua et al., 1985; Edwards et al., 1987), and TNF $\alpha(D a y e r$ et al., 1985; Brenner et al., 1989). Other collagenase stimulatory agents include steroids (Clark $e t$ al., 1987), $\mathrm{PGE}_{2}$ (Dayer et al., 1976, 1978; Wahl et al., 1977), endotoxin(Wahl et al., 1974), ConA(Hurum et al., 1982; Overall and Sodek, 1990) and phagocytosis(Werb and Reynolds, 1974). Cell shape changes, actin depolymerization(Harris and Krane, 1971; Unemori and Werb, 1986; Werb et al., 1986), and cellular interaction with connective tissue components through integrins(Werb et al., 1989) also stimulate the induction of collagenase and stromelysin expression.

Stromelysin mRNA levels are also elevated by IL-1 (Frisch and Ruley, 1987), EGF and PDGF(Matrisian et al.,
活性化した䣼素の活性を部分的に阻害するかのいずれかによっ て酵素活性を低下させていることを意味している。

\section{F. MMPとTIMP発現の調節}

\section{F-1. MMPとTIMPの誘薄}

細胞によるMMPタンバクの棈成的発現は、通常はないか 極めて低い。誘導物質によるMMP産生增大の程度は、細胞の種 類や培養条件によって变り、細胞や組織に特異的な発現の構成 的な水準に依存している。棈成的な発現のレベルがどうであっ ても、強力なコラゲナーゼの誘導物質である12-0-tetradecanoylphorbol-13-acetate(TPA)でコラゲナーゼを最大レベルに誘 導すると、どの組織から由来する細胞でもはは一定で、〜3-7 $\mu$ $\mathrm{g} / 106$ 細胞/24hである(Wilhelm 5, 1986)。これとは对照的にTIMP タンパクの構成的発現は高くないが、それにも関らずTIMP mRNAは種々の組織で検出可能である。低いけれども、しかし 検出可能な量のTIMPの転写が一般的には胎児の組織や、皮骨形 成や軟骨内骨化のようなマトリックスが堆積したりつくりかえ られたりしている組織で見出される(Nomura 5，1989)。

TIMPの調節に関する研究は、コラゲナーゼやストロムラ イシンについての研究ほど十分にはなされていない。TIMP遺伝 子の発現は血清、EGF, PDGFやFGFなどの成長因子(Edwardsら，

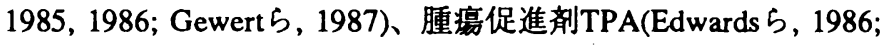
Murphy 5，1985; Clarkら，1985)によって誘導される。しかし分解 系であるMMPsとその阻害戍であるTIMPがこれらの刺激剂によ り共に增大するということは、組織が吸収されていくという現 象としては矛盾しているようにみえる。

MMP遗伝子の転写は種々の生物学的試薬によって促進的 制御を受けている。腫瘍原性ウイルス、TPAやマイトマイシン や紫外線のような腫瘍促進郕はコラゲナーゼ発現を誘導する (Aggeler 5,1984 ; Brinkerhoff $ら, 1979$; Murphy 5,1985 ; Angel 5 , 1986)。コラゲナーゼ合成はIL-1(Murphy 5, 1985; Dayer 5, 1986; Richards $と$ Rutherford, 1990)、PDGF(Bauer 5,1985 ; Chua 5 , 1985)、EGF(Chua 5, 1985; Edwards 5,1987 )、TNF $\alpha$ (Dayer 5 , 1985; Brennerら，1989)などのサイトカインや成長因子によって もまた励起される。他のコラゲナーゼ励起郕としては、ステロ イド(Clark 5, 1987)、PGE2(Dayer 5, 1976, 1978; Wahl5, 1977)、 エンドトキシン(Wahl 5, 1974)、ConA(Hurum 5, 1982; Overall と Sodek, 1990)、荟食作用(WerbとReynolds, 1974)などがある。細 胞の形の変化、アクチンの脱重合(Harris とKrane, 1971; Unemori とWerb, 1986; Werbら,1986)、細胞がインテグリンを介して結合 組織成分と䊅合すること(Werbら , 1989)もまたコラゲナーゼやス トロムライシンの発現の誘導を励起する。

ストロムライシンのmRNA量もまたIL-1(FrischとRuley, 1987)、EGFおよびPDGF(Matrisian 5, 1985a; Kerr ら, 1988b)、 NGF(Machida 5, 1989)、腫瘍への形質転换(Matrisian 5, 1985a; Kerr ら, 1988b)、TPA(Chinら, 1985; Kerrら, 1988a)によって上昇 する。コラゲナーゼとストロムライシンの調節は細胞や組織に 
1985a; Kerr et al., 1988b), NGF(Machida et al., 1989), oncogenic transformation(Matrisian et al., 1985a; Kerr et al., 1988b), and TPA(Chin et al., 1985; Kerr et al., 1988a). The regulation of collagenase and stromelysin is cell and tissue specific and not necessarily coordinated(Wilhelm et al., 1987; Overall et al., 1989; 1991; Overall and Sodek, 1990). However, coordinate expression of stromelysin and collagenase is common(Aggeler et al., 1984; Chin et al., 1985; Frisch et al., 1987; Murphy et al., 1985).

In contrast with other MMPs, MMP-2 appears relatively uninducible. Salo et al.(1985) reported that human fibroblasts in the early log phase of growth produced type IV collagenase (MMP-2), but the levels of expression declined to be undetectable by late log phase, at which point the enzyme was now inducible by TPA. However, Collier et al.(1988) and Overall and Sodek(1990) have found that type IV collagenase is not induced by TPA. Indeed, the MMP- 2 promoter does not have a TRE box(Frisch et al., 1990). In response to other agents, the regulation of MMP-2 also appears distinct(Collier et al., 1988). MMP-2 is induced by TGF-B1(Overall et al., 1989; 1991, see below) but not by IL-1 or TPA and thus differs from the regulation of collagenase and stromelysin which are coordinately regulated by TPA and IL-1(Aggeler $e t$ al., 1984; Murphy et al., 1985; Chin et al., 1985). Of note, active and latent $72 \mathrm{kD}$ gelatinases are found in high amounts in developing tooth enamel, at sites shown to also contain abundant levels of TGF- $\beta 1$ mRNA(Overall and Limeback, 1988). Although many cells constitutively synthesize MMP-2, the $92-\mathrm{kD}$ gelatinase is only secreted by some tumor cells, macrophages, and epidermal keratinocytes. However, EGF, TPA, and IL-1 induce the expression of 92-kD gelatinase, but not MMP-2, in U937, HT1080 cells, and SV40-transformed fetal lung fibroblasts(Wilhelm $e$ t al., 1989).

Collagenase synthesis and mRNA levels are repressed by dexamethasone and retinoic acid(Brinkerhoff et al., 1980; Saus et al., 1988), although retinoic acid stimulates collagenase induction in rat bone cells(Otsuka et al., 1984). Interferon$\gamma$ (IFN- $\gamma$ ) has also been shown to reverse the stimulation of bone cell collagenase by 1,25 -dihydroxy vitamin $D_{3}[1,25$ $(\mathrm{OH})_{2} \mathrm{D}_{3}$ ], parathyroid hormone, IL-1, $\mathrm{PGE}$, and TNF $\alpha$ (Shen et al., 1988). Recent studies have established a regulatory role for TGF- $\beta 1$ in the expression of fibroblast and osteoblast collagenolytic activity. TGF- $B 1$ was found to suppress collagenase activity directly, by decreasing collagenase transcription and synthesis, and indirectly, by differentially increasing TIMP and PAI-1 synthesis(Edwards et al., 1987; Overall et al., 1989; 1991). The general reduction in proteolytic activity by TGF-B1 would augment the synthesis of extracellular matrix, a process stimulated by TGF-B1(Wrana et al., 1986,1991). However, TGF- $B 1$ increases the expression of $72-\mathrm{kD}$ gelatinase(Overall et al., 1989; 1991) and, in contrast to the effects on TIMP, TGF-
特異的で、必ずしも共役していない(Wilhelm ら, 1987; Overallら, 1989, 1991; Overall とSodek, 1990)。しかしストロムライシンとコ ラゲナーゼの共役した調節が普通である(Aggelerら, 1984; Chin 5, 1985; Frisch 5, 1987; Murphy 5, 1985)。

他のMMPsと異なり、MMP-2は比較的誘導されにくいよう にみえる。Saloら(1985)によると、ヒト線維芽細胞が対数增殖期 の初期にIV型コラゲナーゼ(MMP-2)を産生するが、对数增殖期 の後期には発現量は減少して検出できなくなる。この時期に TPAで処理すると酳素が誘導されると言う。しかしながら、 Collierら(1988)とOverall とSodek(1990)はIV型コラゲナーゼは TPAによって誘導されないことを見出している。たしかに、 MMP-2プロモーターはTREボックスをもっていない(Frischら， 1990)。他の試薬に対する応答でも、MMP-2の調節は異なって いるようだ(Collier ら, 1988)。MMP-2はTGF- $\beta$ 1(Overall ら, 1989, 1991，後述)によって誘導されるがIL-1 PTPAでは誘導されな い。このように、TPAやIL-1で共役的に調節をうけるコラゲナ 一ゼやストロムライシンの調節とは違っている(Aggelerら,1984; Murphy 5, 1985; Chinら, 1985)。注目すべきことに、活性型及び

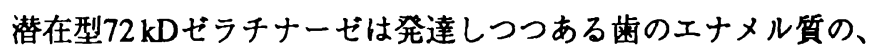
特にTGF- $\beta 1 \mathrm{mRNAを}$ 豊富に含有している所に非常に多く存在 する(Overall、Limeback1988)。多くの細胞がMMP-2を構成的に 合成するが、92 kDゼラチナーゼはある種の腫瘍細胞、マクロ ファージ、表皮のケラチン細胞によってのみ分泌される。しか し、U937、HT1080細胞、SV-40で形質転換した胎児の肺線維芽 細胞に於ては、EGF、TPA、IL-1は92kDゼラチナーゼの発現を 誘導するが、MMP-2は誘導されない(Wilhelm5, 1989)。

コラゲナーゼの合成とmRNAレベルはデキサメタゾンとレ チノイン酸によって抑制される(Brinkerhoffら，1980; Sausら， 1988)がレチノイン酸はラットの骨細胞ではコラゲナーゼ誘導を 励起する(Otsukaら，1984)。またインターフェロン $\gamma($ IFN- $\gamma)$ は、1,25-ジヒドロキシビタミンD3[1,25-(OH)2D3]、バラサイロ イドホルモン、IL-1、PGE2、TNF $\alpha$ による骨細胞コラゲナーゼ の增大を抑えることが示されている(Sehenら，1987)。最近の研 究で、TGF- $\beta 1$ が線維芽細胞や骨細胞のコラーゲン分解活性の 発現の調節に関わっていることが明らかとなった。TGF- $\beta 1$ は、直接にはコラゲナーゼの転写と合成を減少させ、間接的に はTIMPとPAI-1合成を差次的に增大させることによって、コラ ゲナーゼ活性を抑制していることが見出された(Edwardsら， 1987; Overallら, 1989, 1991)。TGF- $\beta$ 1によってタンパク分解活 性が一般に减少するということは、細胞外マトリックス合成が TGF- $\beta$ 1の刺激によって增大しているようにみせることになる (Wranaら, 1986)。しかしながら、TGF- $\beta 1$ は72 kDゼラチナーゼ の発現を增加させ(Overall5, 1989, 1991)TIMPに対するのとは異 なりTIMP-2の発現を减少させる(Stetler-Stevenson 5, 1990)の で、MMP-2の活性は增強される。長期間培養したMRC-5線維芽 細胞でも、TGF- $\beta 1$ はEGFやFGFによって誘導されるコラゲナ 一ゼ量を減少させ、EGFやFGFによって誘導されるTIMP量を増 
B1 decreases the expression of TIMP-2(Stetler-Stevenson $e$ t al., 1990), an action that would potentiate the activity of MMP2. TGF- $B 1$ also reduces the level of collagenase expression induced by EGF and FGF in late passage MRC-5 fibroblasts and amplifys the induction of TIMP by EGF and FGF(Edwards $e t$ al., 1987). The EGF induction of stromelysin mRNA is also repressed by TGF-B1(Matrisian et al., 1986b, Machida et al., 1988; Kerr et al., 1988a), serum(Matrisian et al., 1985a), and dexamethasone(Frisch and Ruley, 1987).

In all cases examined, the increase in MMP expression results from transcriptional activation with increases in the collagenase and stromelysin mRNA levels occurring within 5-8 h of TPA stimulation(Brinkerhoff et al., 1982; Gross et al., 1984; Frisch et al., 1987). After collagenase induction, corresponding increases in the synthesis and export of the collagenase protein soon follows, with no storage of the enzyme within the cell (Valle and Bauer, 1979). MMP-2 is upregulated by TGFB1 through increased transcription and through increased mRNA stability(Overall et al., 1991). In rabbit synovial cells, collagenase mRNA degradation is decreased following TPA stimulation, but the decreased mRNA levels following retinoic acid or dexamethasone treatment did not result from reduced mRNA stability(Brinkerhoff $e t$ al., 1986). Similarily, the decrease in collagenase mRNA levels following TGF-B1 treatment does not result from decreased mRNA stability (Overall et al., 1991).

\section{F-2. Intracellular pathways}

TPA stimulation of collagenase(Angel et al., 1986, 1987a,b) and stromelysin(Kerr et al., 1988b) gene transcription involves FOS, the product of c-fos, which is transiently induced following TPA stimulation(Angel et al., 1987a). The activator protein-1(AP-1) complex is a FOS/JUN heterodimer which binds to the nucleotide sequence TGAg/cTCA, termed the TPA response element(TRE), in the collagenase promoter(Lee et al., 1987; Angel et al., 1987a, b).

Protein kinase $\mathrm{C}$ activity appears to be critically important in the induction of collagenase and stromelysin. The majority of the known effects of TPA are mediated through protein kinase $C$ activity(see review by Nishizuka, 1988). In addition, the stimulation of collagenase expression by TNF $\alpha$, which also stimulates protein kinase $\mathrm{C}$ activity, is blocked in the presence of a protein kinase C inhibitor(Brenner et al., 1989). The TRE box is also present in the stromelysin promoter and growth factor induction of stromelysin expression utilizes this element (Kerr et al., 1988b). Experiments utilizing c-fos antisense mRNA and protein kinase $C$ depletion have revealed that PDGF induces stromelysin transcription through a FOS-dependent pathway that is independent of protein kinase $\mathrm{C}$ activity (Kerr et al., 1988b). In contrast, EGF and TPA induction of stromelysin requires protein kinase $\mathrm{C}$ activity, but unlike TPA and PDGF, EGF does not induce stromelysin through FOS
強する(Edwardsら, 1987)。ストロムライシンmRNAのEGFによ る誘導は、TGF- $\beta$ 1(Matrisian 5,1986 ; Machida 5,1988 ; Kerr 5 , 1988a)、血清(Matrisian ら，1985)、デキサメサゾン(Frischと Ruley, 1987)によっても同様に抑えられる。

調べられている全ての場合に於て、MMP発現の増加は、 TPA刺激後5〜8時間でおこるコラゲナーゼやストロムライシン mRNA量の增加を伴う転写の活性化からもたらされている (Brinkerhof 5, 1982; Gross 5, 1984; Frisch5, 1987)。コラゲナー ゼ誘導のあと、コラゲナーゼタンパクの合成と分泌の增加がす ぐに続き、細胞内に酵素は貯えられることはない(ValleとBauer, 1979)。MMp-2はTGF- $\beta 1 に よ り$ 転写の增加とmRNA安定性が增 大することで、增加方向に調節を受けている(Overall5, 1991)。 ウサギの滑膜細胞では、コラゲナーゼのmRNAの分解はTPA刺 激の後減少する。しかし、レチノイン酸やデキサメサゾン処理 後のmRNA量の減少は、mRNAの安定性が低下したためにもた らされたのではない(Brinkerhoff 5,1986$) 。$ 同様に、TGF- $\beta 1$ 処 理後のコラゲナーゼのmRNA量の減少は、mRNAの安定性の減 少が原因ではない(Overallら, 1991)。

\section{F-2. 細胞内経路}

TPAによるコラゲナーゼ(Angelら，1986, 1987a,b)とストロ ムライシン(Kerrら, 1988b)遺伝子の転写の励起は、c-fosの産物 であるFOSが関係している。FOSはTPA刺激後一時的に誘導さ れる(Angelら, 1987a)。アクチベータータンパク-1(AP-1)複合体 はFOS/JUN異種二量体であってコラゲナーゼブロモーター中に あるTPA応答エレメント(TRE)と名付けられているTGAg/cTCA というヌクレオチド配列と結合する(Leeら, 1987; Angel 5, 1987 a, b)。

プロテインキナーゼC活性がコラゲナーゼやストロムライ シンの誘導に決定的に重要であるようにみえる。今までに知ら れているTPAの効果の大部分は、ブロテインキナーゼC活性を 介するものである(Nishizukaによる総説, 1988)。さらに、プロテ インキナーゼCを励起できるTNF $a$ によコラゲナーゼの発現 の增加はプロテインキナーゼC 阻害剂の存在下では妨げられる (Brennerら, 1989)。TREボックスは、ストロムライシンのプロモ ーター中にも存在し、成長因子によるストロムライシン発現の 誘尊にはこのエレメントが用いられる(Kerrら, 1988b)。c-fosの アンチセンスmRNAを用いたり、プロテインキナーゼC欠損状 態での実験から、プロテインキナーゼCとは無関係のFOS-传存 性の経路によって、PDGFはストロムライシンの転写を誘導す ることが明らかとなった(Kerrら，1988b)。これに対し、ストロ ムライシンのEGFやTPAによる誘導はプロテインキナーゼC活 性を必要とするが、TPAやPDGFとは異なり、EGFはストロムラ イシンの誘導にFOSを介さない(Kerrら, 1988b)。

cAMPの量もTPAやIL-1によって著しく上昇するが、cAMP 産生の增加には間接的にPGE2が介在している(Dayerら, 1978)。 TPAはまた、PGE2の強力な励起剤でもあるが、インドメタシン 存在下でもTPAはコラゲナーゼ発現を刺激し続ける(Brinkerhof 
(Kerr et al., 1988b).

cAMP levels are also markedly elevated by TPA and by $\mathrm{IL}-1$, but the increase in cAMP production is indirectly mediated by $\mathrm{PGE}_{2}$ (Dayer $e t$ al., 1978). TPA is also a potent stimulator of $\mathrm{PGE}_{2}$ synthesis, but TPA in the presence of indomethacin continues to stimulate collagenase expression(Brinkerhoff $\boldsymbol{e t}$ al., 1979) indicating that the TPA induction of collagenase is not mediated by $\mathrm{PGE}_{2}$ or cAMP. Indeed, cAMP is involved in the repression of stromelysin expression(Kerr et al., 1988a). However, TGF- $B 1$ does not elevate $C A M P$ levels, indicating that the TGF- $B 1$ repression of stromelysin expression occurs through another pathway. Other second messenger systems have also been investigated for their possible involvement in collagenase induction. However, the addition of $\mathrm{Ca}^{++}$ionophores, cAMP, or arachidonic acid did not induce collagenase in human fibroblasts(Brenner et al., 1989).

Recently, a TGF- $\beta$ inhibitory element (TIE), GNNTTGGtGA, has been identified in the promoter regions of stromelysin and collagenase that is involved in the inhibition of gene transcription(Kerr et al., 1990). Of interest, a FOS-containing complex was shown to bind to this element, implicating this transcription factor in both the stimulation and inhibition of stomelysin and collagenase transcription(Kerr et al., 1990). Since a family of JUN proteins exists, different FOS/JUN complexes may recognize the TRE and TIE sequences which may account for this specificity.

\section{F-3. MMP Regulation by Lectins}

Receptor aggregation and endocytosis is thought to be an important aspect of some transmembrane signaling mechanisms. ConA is known to trigger fibroblast cell membrane capping and endocytosis(Rosenblith et al., 1973) and may therefore mimic physiological pathways of cellular activation. Indeed, Con A is known to exert various stimulatory or inhibitory effects on cells(reviewed by Sharon and Liz, 1972). For example, ConA stimulates T lymphocyte proliferation and the release of a factor which increases collagenase synthesis by macrophages(Wahl et al., 1975). In macrophages, ConA increases plasminogen activator synthesis(Vasali et al., 1977) and has also been shown to release MCF/catabolin/IL-1, which is a potent stimulator of MMP production by rheumatoid synovial cells(Dayer et al., 1977) and synovial tissue(Saklatvala and Dingle, 1980). ConA, but not the lectins pokeweed mitogen or wheat germ agglutinin, increases the synthesis of collagenase both in fibroblasts(Hurum et al., 1982; Wang et al., 1983; Overall and Sodek, 1990) and osteoblasts(Otsuka et al., 1984).

We have recently investigated the effects of ConA on fibroblast collagenolytic activity(Overall and Sodek, 1990). The actions of ConA were characterized by both an increased expression and activation of MMPs and a reduced expression of TIMP and TIMP-2. Although MMP synthesis was increased by Con A, different levels of stimulation of collagenase, MMP-
ら, 1979)ので、TPAによるコラゲナーゼの誘導はPGE2やcAMP を介していないことがわかる。実際、cAMPはストロムライシ ン発現の抑制に関与している(kerrら, 1988a)。しかし、TGF- $\beta 1$ はcAMP量を增加させないので、TGF- $\beta 1$ によるストロムライシ ン発現の抑制は別の経路を通っておきているのであろう。別の 第二情報伝達系がコラゲナーゼ誘導に関与しうるかどうかも研 究されているが、 $\mathrm{Ca}^{++}$イオノフォア、cAMP、アラキドン酸は ヒト線維芽細胞の系ではコラゲナーゼを誘導しなかった(Brenner 5, 1989)。

最近、TGF- $\beta 1$ 阻害エレメント(TIE)、つまり GNNTTGGtGAがストロムライシンとコラゲナーゼのプロモー ター領域にあり、遺伝子の転写の阻害をしていることが確認さ れた(Kerrら，1990)。面白いことには、FOSを含む複合体がこの エレメントに䊅合することが示された、この転写因子はストロ ムライシンとコラゲナーゼの転写の励起と阻害の両方に関与し ていることになる(Kerrら, 1990)。JUNタンパクにはファミリー があるので、異なるFOS/JUN複合体がTREとTIE配列を認識す るということで、この特異性が説明できるかも知れない。

\section{F-3.レクチンによるMMPの調節}

受容体の集合とエンドサイトーシスは、膜を通過する情報 伝達機構を考える上で重要な現象であると思われる。ConAは線 維芽細胞膜のキャッピングヤエンドサイトーシスの引き金にな ることが知られているので(Rosenblithら，1973)、細胞が活性化 される時の生理的な経路を模做するよい系となる。事実、ConA は細胞に対して様々の励起あるいは阻害的効果を及はすことが 知られている(SharonとLizによる総説, 1972)。例えば、ConAは Tリンバ球を刺激して增殖させ、マクロファージにコラゲナー ゼ合成を盛んにさせるような因子の分泌を促進する(Wahl 5， 1975)。マクロファージに対しては、ConAはプラスミノーゲン アクチベーター合成を盛んにし(Vasaliら, 1977)、そしてMCF/カ タボリン/IL-1を放出させることが示されていて、この物質は リューマチの滑膜細胞(Dayerら, 1977)及び滑膜組織(Sakatvala と Dingle, 1980)によるMMP産生を強く励起させるものである。ア メリカヤマゴボウレクチンや小麦胚凝集素では駄目だが、ConA は線維芽細胞(Hurum 5，1982; Wang ら, 1983; OverallとSodek, 1990)や骨細胞(Otsuka 5, 1984)どちらに対してもコラゲナーゼ合 成を增加させる。

最近、我々は線維芽細胞のコラゲナーゼ活性に対する ConAの効果について研究した(Overall とSodek, 1990)。ConAの 作用はMMPsの発現の増加と活性化、TIMP-2発現の低下という 極めて特徵的なものであった。MMP合成はConAによって増加 するが、コラゲナーセ、、MMP-2、パンプ1に対する励起の程度 はそれぞれ異なっていて、MMPsは個々別々に調節をうけてい ることを示す結果が得られた。MMP-2とTIMP、TIMP-2が逆方 向に調節されているので、MMP発現のみの增加によって得られ る䊅果より、その分解活性はずっと大きいものになる。この独 特なConAの線維芽細胞に対する刺激は、他の成長因子やホルモ 
2 and Pump-1 were observed indicating that the MMPs are regulated individually. The reciprocal regulation of MMPs and TIMP and TIMP-2 would achieve a greater degradative activity than that obtained by increases in MMP expression alone. This appears to be a unique feature of the ConA stimulation of fibroblasts that has not been previously demonstrated with other growth factors or hormones.

An additional aspect of the regulation of MMP expression by ConA was the endogenous activation of collagenase and MMP-2. This is significant because, although some active collagenase and MMP-2 are released from organ cultures active collagenase and MMP-2 have rarely been reported in short term cell cultures. Moreover, since the activation of collagenase and MMP-2 did not occur as a result of either plasmin or stromelysin activity, the presence of other MMP activators that may also be important in vivo is indicated. Since PUMP-1 can activate collagenase, the ConA induction of Pump-1 provides a possible explanation for the activation of collagenase and MMP- 2 in these cultures.

$\alpha$-Methyl mannoside blocked the effects of ConA on MMP and TIMP expression, thus ConA appears to initiate its effects by binding and crosslinking cell surface proteins and receptors. Since ConA interacts with many types of cell surface receptors and molecules, ConA may mimic the "multiple hits" that a cell responds to in the tissue milieu. Thus, although ConA is not a physiological cell activator, the receptor stimulation and intracellular signals induced by ConA in vitro may be more physiological than the "single hit" produced by a growth factor or hormone added alone to cell cultures.

The regulation of MMP and TIMP gene expression by ConA indicates that naturally occurring lectins may also regulate MMP expression in vivo. Indeed, collagenase secretion by fibroblasts also occurs coincident with phagocytosis(Werb and Reynolds, 1974). In these processes the recognition processes are mediated, in part, through lectin-carbohydrate interactions. Indeed, lectin-induced phagocytosis in macrophages and polymorphonuclear leukocytes is recognized as a distinct process, lectinophagocytosis, and $N$-acetylgalactosamine- and mannosespecific lectins involved in lectinophagocytosis have been isolated from macrophages(Blackwell et al., 1985; Kan and Bennett, 1988). Lectins have been isolated from a variety of transformed cells(reviewed by Raz and Lotan, 1987), and mannose specific lectins are involved in cell adhesion and implicated in the formation of metastatic emboli(Gabius et al., 1985). Other mannose-specific lectins facilitate the binding of metastatic cells to endothelial surfaces, laminin, and type IV collagen (Dennis et al., 1984). Thus, it is possible that tumor cell lectins and bacterial cell surface lectins may increase MMP expression in the surrounding normal tissue cells and thereby facilitate tissue invasion by tumor cells or bacteria.
ンで今までに示されたことのないものである。

さらにConAによるMMP発現調節を別の観点で見ると、コ ラゲナーゼとMMP-2が内在的に活性化されているということで ある。このことは重要なことである、というのは、活性型のコ ラゲナーゼやMMP-2は組織培養では分泌されるが、短期間の細 胞培養での活性型コラゲナーゼやMMP-2は殆んど報告されてい ないからである。その上、コラゲナーゼとMMP-2の活性化がブ ラスミンやストロムライシンによってもたらされなかったの で、in vivoに於いて別のMMP活性化物質が存在して、その重要 な硣らきをしているということが示されているからである。パ ンプ1はコラゲナーゼを活性化できるので、ConAがパンプ1を誘 導すればこれらの培養系におけるコラゲナーゼとMMP-2活性化 を説明することができよう。

$\alpha$ ーメチルマンノシドを加えるとConAによるMMPとTIMP の発現の効果を阻止するので、ConAは細胞表面タンパクや受容 体と䊅合して交差結合をすることでその効果を表わすのであろ う。ConAは多くの種類の細胞表面受容体や分子と反応するの で、ConAは組織環境内で細胞が応答している「マルチブルヒッ ト」とよく似たものと考えてよいのではないだうか。このよ うに、ConA は生理的な細胞活性化物質ではないが、in vitroで ConAによって惹き起こされる受容体の刺激や細胞内へのシグナ ル伝達は、成長因子やホルモンが培養系に単独に加えることに よって生じる「シングルヒット」より、より生理的であるかも しれない。

MMPとTIMP遗伝子発現のConAによる調節は、天然に存在 するレクチンがin vivoでMMP発現を調節している可能性を示し ている。実際、線維芽細胞によるコラゲナーゼの分泌は喰作用 と同時に起こる(WerbとReynolds, 1974)が、喰作用の過程に於け る認識は、少くもある部分は、レクチンー炭水化物相互作用を 介しているのである。事実、マクロファージと多形核白血球に おいてレクチンで誘導される喰作用は、レクチノファゴサイト ーシスという別の過程と考えられていて、このレクチノファゴ サイトーシスに関与しているN-アセチルガラクトサミンー及び マンノースー特異的レクチンがマクロファージから単離されて いる(Blackwellら, 1985; KanとBennett, 1988)。レクチンは種々の 腫瘍形質転換細胞からも単離されていて $(\operatorname{Raz}$ とLotanの総説, 1987)、マンノースに特異的なレクチンは細胞の接着に関与し、 また転移性塞栓細胞塊の形成にも関与している(Gabiusら, 1985)。又、別のマンノース特異的レクチンは転移性細胞が血管 内皮の表面や、ラミニン、IV 型コラーゲンに䊅合することを促 進させる(Dennisら,1984)。このようにして、腫疸細胞のレクチ ンや細菌の細胞表面のレクチンが周囲の正常組織細胞のMMP発 現を増加させ、それによって、腫瘍細胞や細菌の組織へ浸潤が 促進される可能性がある。

愛知県がんセンター研究所 病態学研究室

山形 貞子 訳 


\section{Acknowledgement}

CMO is supported by a Centennial Fellowship from the

Canadian Medical Research Council.

\section{References}

Abe, S., and Nagai, S. (1972) J. Biochem. 71, 919-922

Aggeler, J., Frisch, S. M., and Werb, Z. (1984) J. Cell Biol. 98, 1662-1671

Angel, P., Poting, A., Mallinck, U., Rahmsdorf, H., Schorpp, M., and Herrlich, P. (1986) Mol. Cell. Biol. 6, 1760-1766

Angel, P., Baumann, I., Stein, B., Delius, H., Rahmsdorf, H. J., and Herrlich, P. (1987a) Mol. Cell. Biol. 7, 2256-2266

Angel, P., Imagawa, M., Chiu, R., Stein, B., Imbra, R.J., Rahmsdrof, H. J., Jonat, C., Herrlich, and Karin, M. (1987b) Cell 49, 729-739

Bauer, E. A. and Vallee, K-J. (1982) J. Invest. Dermatol. 79, 398-402

Bauer, E. A., Stricklin, G., Jeffrey, J., and Eisen, A. (1975) Biochem. Biophys. Res. Comm. 64, 232-240

Bauer, E. A., Cooper, T. W., Hunag, J. S., Altman, J., and Deuel, T. F. (1985) Proc. Natl. Acad. Sci. USA 82, $4132-4136$

Birkedal-Hansen, H. and Taylor, R. E. (1982) Biochem. Biophys. Res. Comm. 107, 1173-1178

Blackwell, J. M., Ezekowitz, R. A. B., Roberts, M. B., Channon, J. Y., Sim, R. B., and Gordon, S. (1985) J. Exp. Med. 162, 324-331

Boone, T. C., Johnson, M. J., DeClerk, Y. A., and Langley, K. E. (1990) Proc. Natl. Acad. Sci. USA 87, $2800-2804$

Breathnach, R., Matrisian, L., Gesnel, M., Staub, A., and Leroy, P. (1987) Nucleic Acid Res. 15, 1139-1151

Brenner, D. A., O'Hara, M., Angel, P., Chojkier, M., and Karin, M. (1989) Nature 337, 661-663

Brinckerhoff, C. E., McMillan, R. M., Fahey, J. V., and Harris, E. D., Jr. (1979) Arthritis Rheum. 22, 1109-1116

Brinckerhoff, C. E., McMillan, R. M., Dayer, J. -M., and Harris, E. D. Jr. (1980) N. Engl. J. Med. 303, 432-235

Brinckerhoff, C. E., Grass, N., Nagase, H., Sheldon, L. A., Jackson, R., and Harris, E. J. (1982) Arch. Biochem. Biophys. 241, 26-45

Brinckerhoff, C. E., Plucinska, I., Sheldon, L., and O'Connor, G. (1986) Biochemistry 25, 6378-6384

Burgeson, R. E. (1988) Ann. Rev. Cell Biol. 4, 551-577

Carmichael, D. F., Sommer, A., Thompson, R. C., Anderson, D. C., Smith, C. G., Welgus, H. G., and Stricklin, G. P. (1986) Proc. Natl. Acad. Sci. USA 83, 2407-2411

Cawston, T. E., Galloway, W. A., Mercer, E., Murphy, G., and Reynolds, J. J. (1981) Biochem. J. 195, 159-165

Cawston, T. E., Murphy, G., Mercer, E., Galloway, W. A., Hazelman, B. L., and Reynolds, J. J., (1983) Biochem. J. 211, $313-318$

Chin, R. J., Murphy, G., and Werb, Z. (1985) J. Biol. Chem. 260, 12367-12376

Chua, C. C., Geiman, D. E., Keller, G. H., and Ladda, R. L. (1985) J. Biol. Chem. 260, 5213-5216

Clark, S., Kobayashi, D. K., and Welgus, H. G. (1987) J. Clin. Invest. 80, 1280-1288

Clark, S. D., Wilhelm, S. H., Stricklin, G. P., and Welgus, H. G. (1985) Arch. Biochem. Biophys. 241, 36-44

Collier, I. E., Wilhelm, S. M., Eisen, A. Z., Marmer, B. L., Grant, G. A., Seltzer, J. L., Kronberger, A., He, C., Bauer, E. A., and Goldberg, G. I. (1988) J. Biol. Chem. 263, 6579-6587

Cooper, T. W., Eisen, A. Z., Stricklin, G. P., and Welgus, H. G. (1985) Proc. Natl. Acad. Sci. USA 82, 2779-2783

Dayer, J., Krane, S., Russell, R., and Robinson, D. (1976) Proc. Natl. Acad. Sci. USA 73, 945-949

Dayer, J. M. and Krane, S. M. (1978) Clin. Rheum. Dis. 4, 517-537

Dayer, J. M., Beutler, B., and Cerami, A. (1985) J. Exp. Med. 162, 2163-2168

Dayer, J. M., de Rochemonteix, B., Burrus, B., Demczuk, S., and Dinarello, C. A. (1986) J. Clin. Invest. 77, 645-648

De Clerk, Y. A., Yean, T -S., Ratzkin, B. J., Lu, H. S., and Langley, K. A. (1989) J. Biol. Chem. 264, 17445-17453

Dennis, J. C., Waller, C. A., and Schirrmacher, V. (1984) J. Cell Biol. 99, 1416-1423

Docherty, A.P., Lyons, A., Smith, B. J., Wright, E. M., Stephens, P. E., Harris, T. J., Murphy, G., and Reynolds, J. J. (1985) Nature 318, 66-69

Drouin, L., Overall, C. M., and Sodek, J. (1988) J. Periodontal Res. 23, 370-377

Edelson, P. J. and Cohn, Z. A. (1974) J. Exp. Med. 140, 1364-1386

Edwards, D. R., Parfett, C. L., and Denhardt, D. T. (1985) Mol. Cell. Biol. 5, 3280-3288

Edwards, D., Waterhouse, P, Holman, M. -L., and Denhardt, D. T. (1986) Nucleic Acids Res. 14, 8863-8878

Edwards, D. R., Murphy, G., Reynolds, J. J., Whitham, S. E., Docherty, A. J. P., Angel, P., and Heath, J. K. (1987) EMBO J. 6, $1899-1904$

Eeckhout, Y. and Vaes, G. (1977) Biochem. J. 166, 21-29

Fini, M. E., Plucinska, I., Mayer, A., Gross, R. H., and Brinckerhoff, C. E. (1987a) Biochemistry 26, 6156-6162

Frisch, S. M. and Ruley, H. E. (1987) J. Biol. Chem. 262, 16300-16304

Frisch, S. M., Clark, E. J., and Werb, Z. (1987) Proc. Natl. Acad. Sci. USA 84, 2600-2604

Frisch, S. M., Reich, R., Collier, I. E., Genrich, L. T., Martin, G., and Goldberg, G. I. (1990) Oncogene 5, 75-83

Gabius, H. J., Engelhardt, R., Casper, J., Reile, D., Schumacher, S., Schmoll, J. H., Graupner, G., and Cramer, F. (1985) Tumor Biol. 6, 471-482 Gewert, D., Coulombe, B., Castelino, M., Skup, D., and Williams, B. R. (1987) EMBO J. 6, 651-657

Goldberg, G. I., Wilhelm, S. M., Kronberger, A., Bauer, E. A., Grant, G. A., and Eisen, A. Z. (1986) J. Biol. Chem. 261, 6600-6605

Goldberg, G. I., Marmer, B. L., Grant, G. A., Eisen, A. Z., Wilhelm, S., and He, C. (1989) Proc. Natl. Acad. Sci. USA 86, 8207-8211

Gross, R. H., Sheldon, L. A., Fletcher, C. F., and Brinckerhoff, C. E. (1984) Proc. Natl. Acad. Sci. USA 81, 1981-1985

Harris, E. D. and Krane, S. M. (1971) Arthritis Rheum. 14, 669-684

Hasty, K. A., Hibbs, M .S., Kang, A. H., and Mainardi, C. L. (1984) J. Exp. Med. 159, 1455-1463

Hasty, K. A., Hibbs, M. S., Kang, A. H., and Mainardi, C. L. (1986) J. Biol. Chem. 261, 5645-5650

Hasty, K. A., Stricklin, G., Hibbs, M. S., Mainardi, C. L., and Kang, A. H. (1987) Arthritis Rheum. 30, $695-700$

He, C., Wilhelm, S. M., Pentland, A. P., Marmer, B. L., Grant, G. A., Eisen, A. Z., and Goldberg, G. I. (1989) Proc. Natl. Acad. Sci. USA 86, 2632-2636

Herron, G. S., Banda, M. J., Clark, E. J., Gavrilovic, J., and Werb, Z. (1986) J. Biol. Chem. 261, 2814-2818

Horton, J. E., Wezeman, F. H., and Kuettner, K. E. (1978) Science 199, 1342-1344

Hurum, S., Sodek, J., and Aubin, J. E. (1982) Biochem. Biophys. Res. Comm. 107, 357-366

Ishibashi, M., Ito, A., Sakyo, K., and Mori, U. (1987) Biochem. J. 241, 527-534 
Ito, A. and Nagase, H. (1988) Arch. Biochem. Biophys. 267, 211-216

Kan, V. L. and Bennett, J. E. (1988) J. Infect. Dis. 158, 407-414

Kerr, L. D., Miller, D. M., and Matrisian, L. M. (1990) Cell 61, 267-273

Kerr, L. D., Olashaw, N. E., and Matrisian, L. M. (1988) J. Biol. Chem. 263, 16999-17005

Kuettner, K. E., Soble, L., Croxen, R. L., and Marcznska, D. (1977) Science 196, 653-654

Lee, W., Mitchell, P., and Tjian, R. (1987) Cell 49, 741-752

Lindy, S., Sorsa, T., Suomalainen, K., and Turto, H. (1986) FEBS Lett. 208, 23-25

Machida, C. M., Muldoon, L. L., Rodland, K. D., and Magun, B. E. (1988) Mol. Cell. Biol. 8, 2479-2483

Machida, C. M., Rodlan, K. D., Matrisian, L. M., Magun, B. E., and Ciment, G. (1989) Neuron 2, 1587-1596

Mainardi, C., Hibbs, M., Hasty, K., and Seyer, J. (1984) Coll. Rel. Res. 4, 479-482

Matrisian, L. M., Bowden, G. T., Krieg, P., Furstenberger, G., Briand, J. P., leRoy, P., and Breathnach, R. (1986a) Proc. Natl. Acad. Sci. USA 83, 94113-9417.

Matrisian, L. M., Glaichenhausss, N., Geesnel, M. C., and Breathnach, R. (1985) EMBO J. 4, 1435-1440

Matrisian, L. M., Leroy, P., Ruhlmann, C., Gesnel, M. C., and Breathnach, R. (1986b) Mol. Cell. Biol. 6, $1679-1686$

McKerrow, J. H. (1987) J. Biol. Chem. 262, 5943

Muller, D., Quantin, B., Gesnel, M.-C., Millon-Collard, R., Abecassis, J., and Breathnach, R. (1988) Biochem. J. 253, 187-192

Murphy, G., Cartwright, E., Sellers, A., and Reynolds, J. J. (1977) Biochim. Biophys. Acta 483, 493-498

Murphy, G., Cawston, T. E., and Reynolds, J. J. (1981) Biochem. J. 195, 167-170

Murphy, G., Reynolds, J. J., Bern, U., and Baggliolini, M. (1982) Biochem. J. 203, 209-221

Murphy, G., McAlpine, C., Poll, C., and Reynolds, J. J. (1985a) Biochim. Biophys. Acta 831, 49-58

Murphy, G., Reynolds, J., and Werb, Z. (1985b) J. Biol. Chem. 260, 3079-3083

Murphy, G., Cockett, M. I., Stevens, P. E., Smith, B. J., and Docherty, A. J. P. (1987) Biochem. J. 248, 265-268

Nagase, H. and Barrett, A. J. (1981a) Biochem. J. 193, 187-192

Nagase, H., Jackson, R. C., Brinkerhoff, C. E., Vater, C. A., and Harris, E. D. Jr (1981b) J. Biol. Chem. 256, 11951-11954

Nishizuka (1988) Science 334, 661-665

Nomura, S., Hogan, B. L. M., Wills, A. ., Heath, J. K., and Edwards, D. R. (1989) Development 105, 575-583

O'Grady, R. L., Upfold, L. I., and Stephens, R. W. (1981) Int. J. Cancer 28, 509-515

Okada, Y., Nagase, N., and Harris, E. D., Jr. (1986) J. Biol. Chem. 261, 14245-14255

Okada, Y., Harris, E. J., and Nagase, H. (1988) Biochem J 254, 731-741

Otsuka, K., Pitaru, S., Overall, C. M., Aubin, J. E., and Sodek, J. (1988) Biochem. Cell Biol. 66, 167-176

Otsuka, K., Sodek, J., and Limeback, H. F. (1984) Eur. J. Biochem. 145, 123-129

Overall, C. M., and Limeback, H. Biochem. J. (1988) 256, 965-972

Overall, C. M. and Sodek, J. (1990) J. Biol. Chem. 265, 21141-21151

Overall, C. M., Wrana, J. L., and Sodek, J. (1989 J. Biol. Chem. 264, 1860-1869

Overall, C. M., Wrana, J. L., and Sodek, J. (1991) J. Biol. Chem in press

Pettigrew, D. W., Ho, G. H., Sodek, J., Brunette, D. M., and Wang, H. M. (1978) Arch. Oral Biol. 23, 767-777

Richards, D. and Rutherford, R. B. (1990) J. Periodont. Res. 25, 222-229

Rosenblith, J. Z., Ukena, T. E., Yin, H. H., Berlin, R. D., and Karnovsky, M. J. (1973) Proc. Nat. Acad. Sci. USA 70, 1625-1629

Saklatvala, J. and Dingle, J. T. (1980) Biochem. Biophys. Res. Comun. 96, 1225-1231

Salo, T., Liotta, L. A., and Tryggvason, K. (1983) J. Biol. Chem. 258, 3058-3063

Saus, J., Quinones, S., Otani, Y., Nagase, H., Harris, E. J., and Kurkinen, M. (1988) J. Biol. Chem. 263, 6742-6745

Sellers, A. and Reynolds, J. (1977) Biochem. J. 167, 353-360

Sharon, N. and Liz, H. (1972) Science 177, 949-959

Sharon, N. and Liz, H. (1989) Science 246, 227-246

Shen, V., Kohler, G., Jeffrey, J. J., and Peck, W. A. (1988) J. Bone Mineral Res. 3, 657-666

Sodek, J. and Overall, C. M. (1988) in Biological Mechanisms of Tooth ruption and Root Resorption (Davidovitch, Z. ed.) pp. 303-311, EBSCO

Media, Alabama

Sottrup-Jensen, L. and Birkedal-Hansen, H. (1989) J. Biol. Chem. 264, 393-401

Springman, E. B., Angelton, E. L., Birkedal-Hansen, H., and Van Wart, H. E. (1990) Proc. Natl. Acad. Sci. USA 87, $364-368$

Stetler-Stevenson, W. G., Krutzsch, H. C., Wacher, M. P., Margulies, I. M. K., and Liotta, L. (1989) J. Biol. Chem. 264, 1353-1356

Stetler-Stevenson, W. G., Krutzsch, H. C., and Liotta, L. (1989) J. Biol. Chem. 264, 17374-17378

Stetler-Stevenson, W. G., Brown, P. D., Onisto, M., Levy, A. T., and Liotta, L. A. (1990) J. Biol. Chem. 265, 13933-13938

Stricklin, G. P. (1986) Coll. Res. Rel. 6, 219-228

Stricklin, G., Bauer, E., Jeffrey, J., and Eisen, A. (1977) Biochemistry 16, 1607-1615

Stricklin, G., Eisen, A., Bauer, E., and Jeffrey, J. J. (1978) Biochemistry 17, 2331-2337

Stricklin, G. P., Jeffrey, J. J., Roswit, W. T., and Eisen, A. Z. (1983) Biochemistry 22, 61-68

Tyree, B., Seltzer, J. L., Halme, J., Jeffrey, J. J., and Eisen, A. Z. (1981) Arch. Biochem. Biophys. 208, 440-443

Unemori, E. and Werb, Z. (1986) J. Cell Biol. 103, 1021-1031

Unemori, E. and Werb, Z. (1988) J. Biol. Chem. 263, 16252-16259

Vaes, G. and Eeckhout, Y. (1975) Protides Biol. Fluids 22, 391-397

Valle, K -J. and Bauer, E. A. (1979) J. Biol. Chem. 254, 10115-10122

Van Wart, H. E. and Birkedal-Hansen, H. (1990) Proc. Natl. Acad. Sci. USA 87, 5578-5582

Vassalli, J.- D., Hamilton, J., and Reich, E. (1977) Cell 11, 695-705

Vater, C. A., Harris, E. D., and Siegel, R. C. (1979) Biochem. J. 181, 639-645

Vater, C. A., Nagase, H., and Harris, E. D. (1983) J. Biol. Chem. 258, 9374-9382

Vater, C. A., Nagase, H., and Harris, E. D. (1986) Biochem. J. 237, 853-858 
Wahl, L. M., Wahl, S. M., Mergenhagen, S. E., and Martin, G. R. (1974) Proc. Natl. Acad. Sci. USA 71, $3251-3255$

Wahl, L. M., Olsen, C. E., Sandberg, A. L., and Mergenhagen, S. E. (1977) Proc. Natl. Acad. Sci. USA 74, 255-264

Wang, H. M., Hurum, S., and Sodek, J. (1983) J. Periodontal Res. 18, 149-155

Welgus, H. G., Stricklin, G. P., Eisen, A. Z., Bauer, E. A., Cooney, R. V., and Jeffrey, J. J., (1979) J. Biol. Chem. 254, 1938-1943

Welgus, H. G. and Stricklin, G. P. (1983) J. Biol. Chem. 258, 12259-12264

Welgus, H. G., Grant, G. G., Sacchettini, J. C., Roswit, W. T., and Jeffrey, J. J. (1985) J. Biol. Chem. 260, 13601-13606

Werb, Z. and Reynolds, J. J. (1974) J. Exp. Med. 140, 1482-1497

Werb, Z., Hembry, R. M., Murphy, G., and Aggeler, J. (1986) J. Cell Biol. 102, 697-702

Werb, Z., Tremble, P. M., Behrendtsen, O., Crowley, E., and Damsky, C. H. (1989) J. Cell Biol. 109, 877-889

Wilhelm, S. M., Eisen, A. Z., Teter, M., Clark, C. D., Konberger, A., and Goldberger, G. (1986) Proc. Natl. Acad. Sci. USA 83, $3756-3760$

Wilhelm, S. M., Collier, I. E., Kronberger, A., Eisen, A., Marmer, B. L., Grant, G., Bauer, E., and Goldberg, G. (1987) Proc. Natl. Acad. Sci. USA 84, 6725-6729

Wilhelm, S., Collier, I., Marmer, B., Eisen, A., Grant, G., and Goldberg, G. (1989) J. Biol. Chem. 264, 17213-17221

Wrana, J. L., Sodek, J., Ber, R. L. and Bellows, C. G. (1986) Eur. J. Biochem. 159, 915-924

Wrana, J. L., Overall, C. M., and Sodek, J. (1991) Eur. J. Biochem. 197, 519-528

\section{GLYCONEWS}

Dr. Makoto Ito and Dr. Hisao Nojiri won Japanese Biochemical Society's Shoureisho Awards of 1991

Dr. Makoto Ito, Mitsubishi Kasei Institute of Life Sciences won the Japanese Biochemical Society's Shoreisho Award of 1991 for his study "Discovery of Endoglycoceramidase and Its Activator Protein, Their Applications for Glycosphingolipid Research". Dr. Hisao Nojiri, Jichi Medical School won the same award for his study "Discovery of Leukemic Cell Differentiation-Inducing Activity of Gangliosides: A Novel Aspect for the Molecular mechanism of Cell Differentiation" . That the two of five recipients of this award for 1991 are carbohydrate researchers is a good indication of a high level of activity of carbohydrate research in Japan.
平成 3 年度日本生化学会奨励賞は伊東信博士と野尻久婎博 士に

三菱化成生命科学研究所 伊東信博士が”エンドグリコシ ダーゼびアクチベーターの発見と糖脂質研究への応用”、自 治医科大学 野尻久雄博士が” 細胞の增殖・分化における栍脂 質桾鎖の特異的制御機構と機能: 酸性榶脂質ガングリオシドの白 血病細胞分化誘導活性の発見に基ずく新しい分化機構”で、そ れぞれ平成 3 年度日本生化学会奖励賞を受賞した。5件の受賞者 の内 2 人が糖質研究者に関する研究で占められたのは日本の糖質 研究の隆盛を物語るものである。 